\title{
The Effect of Microteaching On Pre-Service Chemistry Teachers' Teaching Experiences
}

\author{
Hüseyin AKKUŞ ${ }^{\mathrm{a}^{*}}$, Sinem ÜNER ${ }^{\mathrm{a}}$ \\ ${ }^{a}$ Gazi Üniversitesi Gazi Eğitim Fakültesi, Ankara/Türkiye
}

\section{Article Info}

DOI: $10.14812 /$ cuefd.309459

Keywords:

Microteaching

Teaching experience,

Pre-service chemistry teacher.

\begin{abstract}
The purpose of this research is to examine the effect of microteaching on teaching experiences of pre-service chemistry teachers. The research which was a one-group pretest-posttest design study was conducted with 31 pre-service chemistry teachers in a state university in Turkey in 2009-2010 fall semesters. The data of the research was collected by using self-evaluation, group evaluation, peer-evaluation, researchers' evaluations, observer evaluation together with students' self-reflective essays and feedback forms. The data obtained from this study shows that pre-service chemistry teachers lack skills related to teaching experience before applying microteaching. Also the results of this study show that microteaching contributed to the development of communication skills performance, illustrated talk performance, and process skill lesson performance of the pre-service teachers. Moreover, pre-service chemistry teachers realized the deficiencies in their chemistry teaching practices and overcame them, emphasized the relationship between chemistry and daily life more, became more aware of students' misconceptions about chemistry topics due to the microteaching technique.
\end{abstract}

\section{Kimya Öğretmen Adaylarının Öğretim Becerilerine Mikroöğretimin Etkisi}

\section{Makale Bilgisi}

DOI: 10.14812/cuefd.309459

Anahtar Kelimeler

Mikroöğretim

Öğretim deneyimi,

Kimya öğretmen adayı.

\section{Öz}

Bu araştırmanın amacı, kimya öğretmen adaylarının öğretim becerileri üzerine mikro öğretimin etkisini incelemektir. Tek grup öntest-sontest deseninde olan bu çalışma, 2009-2010 güz döneminde Türkiye'deki bir devlet üniversitesinde öğrenim gören 31 kimya öğretmen adayı ile yürütüldü. Araştırmanın verileri; öz-değerlendirme, grup değerlendirme, akran değerlendirme, araştırmacı değerlendirmeleri ve gözlemci değerlendirmeleri ile öğrenci dönüt formları ile toplandı. Çalışma grubundan elde edilen veriler, öğretmen adaylarının uygulamadan önce öğretim deneyimleriyle ilgili becerilerinde eksiklikler olduğunu göstermektedir. Ayrıca, bu çalışmanın sonuçları mikro öğretimin, öğretmen adaylarının iletişim becerileri performansı, gösterim ve sunum performansı ve dersle ilgili süreç becerisi performansının gelişmesinde katkı sağladığını ortaya koymaktadır.

\section{Introduction}

The quality of education we give to the students depends on the quality of teachers (Singh \& Sharma, 2004). The quality of our teachers depends on the quality of teacher education programs. During the past decade a variety of activities and strategies were used in teacher education programs to improve pre-service teachers' abilities and skills. While some of them were temporary, the ones including microteaching are still being used in educational programs in the 21st century (Benton-Kupper,

Author:akkus@gazi.edu.tr 
2001). Microteaching is one of the most effective ways to be able to help pre-service teachers in terms of understanding what teaching means, developing effective teaching skills and how they can help their students better. Since it gives opportunity to put theoretical ideas, which they learn in courses, into practice and instruct by blending teaching abilities, theoretical knowledge, and instructional strategies pre-service teachers have, microteaching is closely connected with teaching actions and an important technique in teacher training (Ambusaidi \& Al-Balushi, 2012; Amobi \& Irwin, 2009; Bell, 2007).

Microteaching was developed in the program of secondary school teacher training in Stanford University in 1960s and was applied in a classroom in which the number of students was few (Allen, 1966). The microteaching circle which was used in Stanford University consists of these steps: making a plan, teaching, observing and criticizing, planning the lesson again, teaching again, making criticisms again and commenting (Brown, 1975; Pauline, 1993). From 1960s onwards, various components such as alternative feedback forms for teachers or recording teachers have been added and also some changes have occurred, however its general philosophy has stayed the same (Benton-Kupper, 2001). The microteaching applications which are frequently used in teacher education provide pre-service teachers to think about their own applications as teachers and encourage them to criticize themselves (Donelly \& Fitzmaurice, 2011).

Microteaching, which corresponds to a real learning environment minimized in terms of time and space, provides pre-service teachers the opportunity to try teaching and get feedback about their performance in a classroom environment. The use of microteaching technique in teacher training programs helps pre-service teachers to grow as effective teachers (Benton-Kupper, 2001; Kpanja, 2001). By this technique, pre-service teachers have a chance of experiencing several teaching applications as taking a role in being both a student and a teacher, and getting ready to become a real teacher ( $\mathrm{Hu}$, 2008). Moreover, recording the process enables pre-service teachers to self-evaluate themselves after the lesson. Pre-service teachers can increase their teaching skills and confidence by observing their own lessons and peers' lessons and bridge between theory and practice in teaching process which is a complex for them. The studies conducted in education show that the use of microteaching technique in teacher training is favorable and it is an important element of teacher training (Benton-Kupper, 2001; Subramaniam, 2006).

If a pre-service teacher does not receive an enough education based on practice before starting her/his profession, she/he will have to face the difficulties directly in his/her profession. When a novice teacher enters a class, she/he teaches with heartbeat and shaking legs having a feeling like swimming in deep waters (Singh \& Sharma, 2004). While microteaching technique helps teachers to eliminate the difficulties and problems that pre-service teachers may face in a classroom environment, at the same time it also provides them the opportunity to increase their self-confidence (Brown, 1975). This technique can be used to obtain clues about pre-service teachers and their teaching abilities before they start their profession and is an element in which it is easy to notice the difference in a pre-service teacher's performance in the first and the following teachings. By using teach, re-teach approach, teaching skills can be evaluated better and criticisms and suggestions can be taken into account. In reteaching, the pre-service teacher can try different learning and teaching strategies with a student group in limited number and continue his/her lesson in accordance with the feedback and reactions she/he got from the students (Allen, 1966; Arsal, 2014; Bell, 2007; Benton-Kupper, 2001). Thus, the teacher will try new methods and receive feedback from students without losing much time. That pre-service teacher has feedback as to good points and points to develop about her/his teaching helps them to reconstruct their teaching process (Allen, 1966; Gee, 1992).

On the other hand, the discussion about microteaching's possible negative effects on pre-service teachers is still ongoing. The criticism about microteaching is focused on pre-service teachers may not cope with real classroom problems because of such controlled classroom environment in microteaching (Cakir \& Aksan, 1992). Moreover, the criticisms of peers or observer and the excitement caused by video camera are known as the disadvantages of microteaching (Erokten \& Durkan, 2009). However, in the situations where a classroom environment cannot be provided, microteaching should make it easier 
to train pre-service teachers (Bakır, 2014). It is necessary not to see microteaching as a technique that can change a pre-service teacher's personality overnight and that can solve all the possible problems that may be faced in classroom environment (Brown, 1975). But it is a technique in which pre-service teachers make connections between their prior knowledge and experiences developing through the process, and also it is a process which helps them to improve their subject matter knowledge and pedagogical content knowledge and could make mistakes among their peers and experts and talk over their mistakes (Fernandez, 2005). After microteaching practices, pre-service teachers feel themselves better in these fields: Motivating students for the lesson, behaving at the student level, directing students' ideas, using appropriate teaching methods, concentrating, overcoming their excitements (Can, 2009).

Studies in the literature show that microteaching has an important role on pre-service teachers in increasing the attitudes that are expected from a teacher, developing content and pedagogical knowledge, enabling to form a connection between theory and practice, reducing anxiety levels (Benton- Kupper, 2001; Darling-Hammond, Hammerness, Grossman, Rust \& Shulman, 2005; Fernandez, 2005; Fernandez \& Robinson, 2006; Kpanja, 2001; Mergler \& Tangen, 2010; Molina, Fernandez \& Nisbet, 2011; Pauline, 1993). Molina et al. (2011) examined the effect of microteaching on elementary preservice mathematics teachers' content and pedagogical content knowledge in the study conducted with pre-service teachers. According to the data obtained from the study, it was concluded that microteaching was beneficial to pre-service teachers in deepening content and pedagogical content knowledge. Fernandez (2010) conducted a study with pre-service mathematics teachers in a course on learning to teach; she found out that microteaching increased subject matter knowledge and improved the abilities to use different instructional strategies to teach content matter. Mergler and Tangen (2010) examined the effect of using microteaching on pre-service teacher proficiency; it was found out that microteaching has positive effect on proficiency beliefs as to pre-service teachers' teaching knowledge and their readiness to teaching profession. Fernandez (2005) conducted a study with 36 pre-service mathematics teachers by using microteaching and found out that microteaching was helpful to preservice teachers in forming a bond between theory and practice by analyzing the lessons others teach and enhanced subject matter knowledge. As a result of the microteaching study on planning the lessons related to pre-service teachers and teaching and getting the comments about teaching and planning these lessons again, Benton-Kupper (2001) and Fernandez and Robinson (2006) identified that preservice teachers described microteaching as a useful teaching experience which is worth spending time. Moreover, pre-service teachers stated that the feedback coming from their peers has quite a positive contribution to their own teaching methods and they also stated that they got the chance to observe and learn different teaching strategies during their peers' lessons. Kpanja (2001) found out that use of microteaching improves the teaching skills of pre-service teachers significantly. Likewise, Pauline (1993) found out that microteaching is technique used successfully in method classes in developing teaching skills and $91 \%$ of teachers find microteaching as beneficial or very beneficial in the studies conducted. Bakır (2014) conducted a study with pre-service science teachers to determine the effect of microteaching on teaching skills of them. It was found that microteaching has a significant effect on teaching skills such as time management, planning, effective communication, classroom management. Cinici (2016) investigated the influence of microteaching on pre-service science teachers' self-efficacy beliefs. It was concluded that microteaching provided a supportive vehicle for enhancing self-efficacy beliefs of pre-service science teachers. Karataş and Cengiz (2016) examined pre-service chemistry teachers' views regarding their microteaching experience. At the end of the study, it was concluded that pre-service chemistry teachers stated that they had problems about time management, planning, choosing objectives in their first presentation. Moreover pre-service chemistry teachers expressed that microteaching method helped them evaluate themselves in many ways related to teaching.

Studies that investigate deeply the impact of the microteaching experience on pre-service teachers' professional learning are very important in terms of enhancing microteaching's potential role in teacher education programs (He \& Yan, 2011). Although microteaching is one of the best ways to help preservice teachers in understanding what teaching means and how they can help their students better, 
what microteaching means is not examined adequately by researchers (Bell, 2007). However, to be able to cope with the difficulties pre-service teaches may face and develop their teaching skills, and for the sake of raising better teachers microteaching technique, which has a positive influence on the developing teacher personality, should be included in teacher training programs appears as an inevitable reality (Bell, 2007; Brown, 1975; Mergler \& Tangen, 2010; Singh \& Sharma, 2004).

When examining the studies in the literature, it is seen that there are studies about various contexts such as the views of pre-service teachers about microteaching (Canbazoğlu Bilici \& Yamak, 2014; Demirbaş \& Afacan, 2013; Gürbüzoğlu Yalmancı \& Aydın, 2014; Karataş \& Cengiz, 2016; Sevim, 2013), the effect of microteaching on pre-service teachers' classroom management attitude and beliefs (Arsal, 2014), the effect of microteaching on teaching skills of pre-service teachers (Bakır, 2014), the effect of microteaching on speaking skills of pre-service teachers (Bulut, Açık, \& Çiftçi, 2016), the effect of microteaching on self-efficacy of pre-service teachers (Cinici, 2016), the effect of microteaching on knowledge of pre-service teachers (Fernandez, 2010; Molina et al., 2011), the effect of microteaching on attitudes and behaviors of pre-service teachers (Uzun, Keleş, \& Sağlam, 2013). In this study, the effects of microteaching applications on communication skills performance, illustrated talk performance, and process skill lesson performance were examined in the context of Special Teaching Methods-II course and this study was conducted with pre-service chemistry teachers during 14 weeks. Moreover preservice chemistry teachers' microteaching applications were evaluated through self assessment, group assessment, peer assessment and researchers' assessments. Thus, microteaching practices of preservice chemistry teachers are evaluated from different aspects. This study addresses the following research questions:

- What is the effect of microteaching on pre-service chemistry teachers' communication skills performance, illustrated talk performance, and process skill lesson performance?

- How are the self-evaluations of pre-service chemistry teachers during microteaching?

\section{Purpose of This Study}

The purpose of this study is to determine the changes in pre-service chemistry teachers' teaching skills by using microteaching technique. Also another purpose of this study is to make pre-service chemistry teachers realize the inadequacies they had before the microteaching sessions in their teaching skills and to make them notice the changes in these skills during the 14 weeks by using different teaching methods in Special Teaching Methods-II course. The skills which were examined in this study were communication skills performance, illustrated talk performance, and process skill lesson performance. Since Special Teaching Methods-II course which takes place teacher training programs contains the first teaching experience of pre-service teachers. Also this course covers use of learning and teaching strategies, preparation and use of teaching materials, and recognition of learning and teaching environment. Because of these reasons, this course is thought to be very important in terms of preservice teachers' trainings (Erokten \& Durkan, 2009).

\section{Method}

\section{Research Design}

The one-group pretest-posttest design was used in this study. In this design, a single group is measured or observed before and after being exposed to a treatment (Fraenkel, Wallen \& Hyun, 2012).

\section{Participants}

This study was conducted in a state university in Ankara, Turkey in 2009-2010 fall semesters. 31 th grade pre-service chemistry teachers were enrolled in the course. 19 of the pre-service teachers were female and 12 of them were male. The participants were studying in a five-year chemistry teacher training program at a faculty of education. The participants of this study were selected by using convenience sampling method. Sometimes convenience samples are the only option a researcher has. 
At such times, a researcher may use this method, but the researcher needs to make a detailed explanation of the sample (Fraenkel et al., 2012). In Turkey, chemistry teacher training program consists of 10 semesters and Special Teaching Methods-I and School Experience-I courses are taken in the 8th semester and Special Teaching Methods -II and School Experience-II courses are taken in the 9th semester and Teaching Experience course is taken in the 10th semester. In the School Experience-I and II courses, pre-service teachers only make observations about teaching and learning process such as teaching methods used by mentor teachers, a student in the classroom, lessons, classroom management, use of textbooks and the questions asked by mentor teachers. Microteaching practice is one of the activities that can be done by pre-service teachers in School Experience-I course. However, the pre-service chemistry teachers in this study didn't do this activity in School Experience-I course because their mentors and school principals didn't give permission for video camera. On the other hand, pre-service teachers make teaching practice in the Teaching Experience course. Pre-service teachers become aware of the characteristics of different teaching approaches, methods and techniques used in chemistry teaching in Special Teaching Methods-I course and apply them in different chemistry topics in Special Teaching Methods-II course. The study was conducted in the course Special Teaching Methods-II given in the 9 th semester 4 hours per week.

\section{Instrument}

In this study, the questionnaire of Pauline (1993) was used by participants in evaluating themselves and their friends after their microteaching sessions. The questionnaire consists of three rating scales. These rating scales are communication skills performance rating scale, illustrated talk performance rating scale and process skill lesson performance rating scale. The best method of giving feedback to the students doing microteaching is through the use of rating scale checklists (Pauline, 1993). The original language of the questionnaire is English. Firstly, the questionnaire translated into Turkish and was checked by a Turkish language expert for language validity. After language validity was provided, the questionnaire was examined by chemistry education experts for content validity. These experts were chemistry educators who taught at undergraduate and graduate levels. The likert type questionnaire consisting of 50 items with 5 options each was used to reveal the changes in participants' skills. All items in the questionnaire were scored as 0 for none, 1 for poor, 2 for average, 3 for good or 4 for very good. In the checklist, communication skills performance consisted of 19 items, illustrated talk performance consisted of 17 items and process skill lesson performance consisted of 14 items. The total score can be obtained from the checklist ranges from 0 to 200. Sample items for the communication skills performance checklist were "The teacher displayed good volume and tone.", "The teacher displayed a high degree of eye contact with students.", "The teacher displayed an awareness of student's needs." and "The teacher displayed wait-time after asking a question." Sample items for the illustrated talk performance checklist were "The teacher captured the students' attention.", "The teacher had all the materials and equipment ready for use." and "The teacher noted the lesson's ending/closure to students." Sample items for the process skill lesson performance checklist were "The teacher linked the lesson to past and or future lesson(s).", "The teacher taught to the lesson's objective(s)." and "The teacher assessed students against the objective(s) which was/were taught."

\section{Research Procedure}

In this study, conducted within Special Teaching Methods-II course, microteaching applications were done for 14 weeks. Participants were evaluated about teaching and communication skills more than the content of the lesson in terms of communication skills, about presenting the lesson in terms of illustrated talk performance and about basic process skills performance and high-level skills in terms of process skill performance. Moreover, in evaluating themselves, their peers or while being evaluated by the observers, participants used the questionnaire. Also, the participant who was lecturing presented her/his self evaluation in written form. The spider web diagram was used by peers as a process evaluation to enable them to notice visually their weak and strong points at the different stages technique used in their first teachings. The research procedure was given in Table 1. 
Table 1.

Research Procedure.

Steps of research procedure

1 Formation of groups from participants

2 Deciding on teaching methods that used by groups

3 Preparation of lesson plans by participants and mentoring about lesson plans by researchers

$4 \quad$ First presentations by participants (recorded by camera)

5 Watching camera records in class and evaluations by researchers, observer and peers

6 Self-evaluation of participant who presents

7 Second presentations by participants (recorded by camera)

8 Watching camera records in class and evaluations by researchers, observer and peers

9 Self-evaluation of participant who presents

Ten groups were formed consisting of 2-4 each from the participants. Firstly, the groups staged the teaching approach which they had chosen and by determining which technique they will use in each stage they prepared a plan. The participants in each group used the same teaching method, but they made their presentations individually in different topics. By this way, participants had a chance to see the practice of ten different teaching methods from different persons. The participants who prepared the plan asked for the feedback by negotiating with the researchers. After that, they presented these lessons to the class in 10-15 minutes. The chemistry topics of participants' microteaching practices were physical and chemical changes, reaction rate, chemical equilibrium, factors affecting solubility, ideal gas laws, separation of mixtures, particular structure of matter, acid strength, exothermic and endothermic reactions and electrochemistry. During the presentation, peers provided feedback by preparing a spider web which showed their strong and weak points at the stages of the chosen approach. The participants' teaching time was recorded by a camera. Then, while the recorded lesson was being watched in the classroom, the participant and her/his peers and researchers evaluated the lesson in accordance with the questionnaire developed by Pauline (1993). After watching the records, the points that the participant did well, the points in which she/he lagged behind, and how she/he could develop the lesson for better, and his strong and weak points were discussed. The suggestions of the researchers and her/his peers were asked for on these issues. Moreover, the participant was given opportunity to do self-evaluation.

The researchers were both observers and evaluators during microteaching practices of participants. They were in the class while participants were doing their teaching practices and criticized the teaching practices of participants. Also researchers helped the participants when the participants asked for help to overcome their shortcomings. For example, some of the participants had problems motivating students to the course and asked for help. The researchers led these participants to give examples from daily life, tell an interesting story, make role play about their chemistry topics. Also some of the participants had problems about knowing possible misconceptions of students and asked for help about this situation. The researchers led these participants to read books, articles and thesis about students' common misconceptions in chemistry and later these participants discussed with researchers about the reasons of these misconceptions and ways to overcome them. In addition to researchers' assessments, the observer evaluation in six different courses which were given by different participants was done by six different experts except the researchers. Two of these experts did their doctorate in chemistry education and four of them are doing their doctorate in chemistry education.

After the first teaching, the participant was given a week to plan the lesson again in accordance with the criticisms and suggestions. During this one week period, the participant revised the lesson plan by meeting with the researchers. Then, she/he taught the same lesson again in 10-15 minutes and the teaching was recorded by the researchers. While watching the record again, the participant evaluated 
herself/himself and her/his peers and the researchers evaluated the participant by using the same questionnaire. After watching the records, by asking the questions such as 'What did the teacher do better this time?', 'What were her/his shortcomings?', and 'How can she/he develop the lesson for better?' the feedback from the class was taken. At the end of the process, the participant made selfevaluation as to weak and strong points in terms of communication skills performance, illustrated talk performance, and process skill lesson performance in written form.

\section{Data Analysis}

In this study, the first and last teachings of each participant were evaluated through self assessment, group assessment, peer assessment and researchers' assessments. In the analysis of these data, Paired Sample t-test was done using SPSS 15.0, because measurement of dependant variable were in interval scale and the dependent variable was normally distributed (Büyüköztürk, 2010). In the analysis of observers' assessments, Wilcoxon Signed Rank was used, because paired observations were independent (Büyüköztürk, 2010). Also, in the written feedback forms and self-evaluations, the descriptive analysis was conducted.

While analyzing the data, for the consistency, six participants' presentations in different teaching approaches which were randomly selected were evaluated by the researchers and three chemistry education experts. The consistency between the researchers' and experts' assessments was calculated by using Kendall's coefficient of concordance and was set as 0.78 . After reaching an agreement for the different views between the researchers and experts, the researchers continued the assessment together.

\section{Result}

Pre-service Chemistry Teachers' Communication Skills Performance, Illustrated Talk Performance, and Process Skill Lesson Performance

According to the data obtained from this study, it is found that there has been an increase in participants' communication skills performance, illustrated talk performance, and process skill lesson performance. Table 2 shows the results of Paired Sample T-Test of the participants in terms of teaching experience skills.

Table 2.

Paired Sample T-Test of the Participants in terms of Teaching Experience Skills.

\begin{tabular}{|c|c|c|c|c|c|c|c|c|}
\hline Assessment Type & $\begin{array}{c}\text { Pre/post- } \\
\text { test }\end{array}$ & $\mathrm{N}$ & $\bar{X}$ & SD & df & $\mathrm{t}$ & $\mathrm{p}$ & $\eta^{2}$ \\
\hline \multirow{2}{*}{ Self Assessment } & Pre-test & 30 & 146.17 & 19.43 & \multirow{2}{*}{29} & \multirow{2}{*}{-9.551} & \multirow{2}{*}{$.000 *$} & \multirow{2}{*}{0.76} \\
\hline & Post-test & 30 & 176.47 & 13.15 & & & & \\
\hline \multirow{2}{*}{ Group Assessment } & Pre-test & 28 & 143.47 & 17.37 & \multirow{2}{*}{27} & \multirow{2}{*}{-11.330} & \multirow{2}{*}{$.000^{*}$} & \multirow{2}{*}{0.83} \\
\hline & Post-test & 28 & 176.73 & 10.03 & & & & \\
\hline \multirow{2}{*}{ Peer Assessment } & Pre-test & 31 & 135.30 & 13.58 & \multirow{2}{*}{30} & \multirow{2}{*}{-14.470} & \multirow{2}{*}{$.000^{*}$} & \multirow{2}{*}{0.87} \\
\hline & Post-test & 31 & 164.65 & 12.18 & & & & \\
\hline \multirow{2}{*}{ Researcher Assessment } & Pre-test & 31 & 117.90 & 21.43 & \multirow{2}{*}{30} & \multirow{2}{*}{-12.425} & \multirow{2}{*}{$.000^{*}$} & \multirow{2}{*}{0.84} \\
\hline & Post-test & 31 & 163.06 & 22.41 & & & & \\
\hline
\end{tabular}

$* \mathrm{p}<.05$.

As seen in Table 2, it is found that there is a significant difference between pre-test and post-test scores, as a result of students' whole skills, self assessment, group assessment, peer assessment and researchers' assessments $(p<.05)$. Meanwhile the average mark of self assessment pre-test is 146.17 before the application, it is deducted that the average mark of self assessment post-test is 176.47 after the application. Moreover, as the average mark of pre-application group assessment pre-test is 143.47, the average mark of post-application group assessment post-test is 176.73 . Whereas the average mark 
of pre-application peer assessment pre-test is 135.30, the average mark of post-application peer assessment post-test is 164.65. In addition to these, as the average mark of pre-application researchers' assessments pre-test is 117.90; the average mark of researchers' assessments post-test is 163.06 after the application. The indications, in terms of the skills that were examined, show that the microteaching affected deeply the participants' teaching experiences. It is clear that microteaching has an effect on teachers' communication, illustrated and process skills. In the considerations of microteaching application results; it is ascertained that there is a progress in both verbal and nonverbal communication skills of participants and in their attitudes during teaching and posing questions. When the postapplication data is examined, it is defined that teachers succeeded in drawing attention in the very beginning of the course and including the students in the process actively by the discussion method. Also, the diversity of materials used by participants during lessons was increased. It is ascertained that, in terms of process skill lesson performance, teachers improved the skills such as realization of the course in a way that the students attend the lesson actively, learn by questioning and searching out the answer of the question on their own; also observe, categorize, operate and experiment during the course.

Table 3.

The Results of Paired Sample T-Test in terms of Communication Skills Performance.

\begin{tabular}{|c|c|c|c|c|c|c|c|c|}
\hline Assessment Type & $\begin{array}{c}\text { Pre/post- } \\
\text { test }\end{array}$ & $\mathrm{N}$ & $\bar{X}$ & SD & $d f$ & $\mathrm{t}$ & $p$ & $\eta 2$ \\
\hline \multirow{2}{*}{ Self Assessment } & Pre-test & 30 & 61.43 & 7.17 & \multirow{2}{*}{29} & \multirow{2}{*}{-5.346} & \multirow{2}{*}{$.000 *$} & 0.50 \\
\hline & Post-test & 30 & 67.43 & 5.88 & & & & \\
\hline \multirow{2}{*}{ Group Assessment } & Pre-test & 28 & 60.87 & 5.83 & \multirow{2}{*}{27} & \multirow{2}{*}{-8.032} & \multirow{2}{*}{$.000^{*}$} & 0.74 \\
\hline & Post-test & 28 & 67.52 & 4.34 & & & & \\
\hline \multirow{2}{*}{ Peer Assessment } & Pre-test & 31 & 56.82 & 4.84 & \multirow{2}{*}{30} & \multirow{2}{*}{-9.881} & \multirow{2}{*}{$.000 *$} & 0.76 \\
\hline & Post-test & 31 & 62.91 & 4.25 & & & & \\
\hline \multirow{2}{*}{ Researcher Assessment } & Pre-test & 31 & 50.35 & 9.083 & \multirow{2}{*}{30} & \multirow{2}{*}{-7.255} & \multirow{2}{*}{$.000^{*}$} & 0.64 \\
\hline & Post-test & 31 & 62.06 & 9.164 & & & & \\
\hline
\end{tabular}

${ }^{*} \mathrm{p}<.05$.

As seen in Table 3, it is procured that there is a significant difference between the pre-test and posttest as a result of self assessment, group assessment, peer assessment and researchers' assessments in terms of communication skills $(p<.05)$. Whereas the average mark of pre-application self assessment, group assessment, peer assessment and researchers' assessments pre-test are respectively, 61.43, $60.87,56.82$ and 50.35; the average marks of post-test are respectively 67.43, 67.52, 62.91 and 62.06 . The indications show that microteaching affected the participants to improve their communication skills significantly.

Table 4.

The Results of Paired Sample T-Test in terms of Illustrated Skills.

\begin{tabular}{|c|c|c|c|c|c|c|c|c|}
\hline Assessment Type & $\begin{array}{c}\text { Pre/post- } \\
\text { test }\end{array}$ & $\mathrm{N}$ & $\bar{X}$ & SD & df & $\mathrm{t}$ & $p$ & $\eta 2$ \\
\hline \multirow{2}{*}{ Self Assessment } & Pre-test & 30 & 46.10 & 8.36 & \multirow{2}{*}{29} & \multirow{2}{*}{-9.370} & \multirow{2}{*}{$.000^{*}$} & \multirow{2}{*}{0.75} \\
\hline & Post-test & 30 & 59.93 & 4.44 & & & & \\
\hline \multirow{2}{*}{ Group Assessment } & Pre-test & 28 & 44.86 & 8.08 & \multirow{2}{*}{27} & \multirow{2}{*}{-10.398} & \multirow{2}{*}{$.000 *$} & \multirow{2}{*}{0.80} \\
\hline & Post-test & 28 & 60.05 & 3.48 & & & & \\
\hline \multirow{2}{*}{ Peer Assessment } & Pre-test & 31 & 42.53 & 5.35 & \multirow{2}{*}{30} & \multirow{2}{*}{-14.814} & \multirow{2}{*}{$.000^{*}$} & \multirow{2}{*}{0.88} \\
\hline & Post-test & 31 & 55.83 & 4.53 & & & & \\
\hline \multirow{2}{*}{ Researcher Assessment } & Pre-test & 31 & 36.19 & 8.34 & \multirow{2}{*}{30} & \multirow{2}{*}{-12.463} & \multirow{2}{*}{$.000 *$} & \multirow{2}{*}{0.84} \\
\hline & Post-test & 31 & 55.54 & 7.70 & & & & \\
\hline
\end{tabular}

$* \mathrm{p}<.05$. 
As seen in Table 4, it's procured that there is a significant difference between the pre-test and posttest as a result of self assessment, group assessment, peer assessment and researchers' assessments in terms of illustrated skills $(\mathrm{p}<.05)$. Whereas the average mark of pre-application self assessment, group assessment, peer assessment and researchers' assessments pre-test in terms of illustrated skills, are respectively 46.10, 44.86, 42.53 and 36.19; the average marks of post-test are respectively 59.93, 60.05, 55.83 and 55.54. The acquired data shows that microteaching is effective on improving the illustrated skills.

Table 5.

The Results of Paired Sample T-Test in terms of Process Skills Lesson Performance.

\begin{tabular}{|c|c|c|c|c|c|c|c|c|}
\hline Assessment Type & $\begin{array}{c}\text { Pre/post- } \\
\text { test }\end{array}$ & $\mathrm{N}$ & $\bar{X}$ & SD & $\mathrm{df}$ & $\mathrm{t}$ & $\mathrm{p}$ & $\eta 2$ \\
\hline \multirow{2}{*}{ Self Assessment } & Pre-test & 30 & 38.63 & 6.17 & \multirow{2}{*}{29} & \multirow{2}{*}{-9.925} & \multirow{2}{*}{$.000 *$} & \multirow{2}{*}{0.77} \\
\hline & Post-test & 30 & 49.10 & 3.82 & & & & \\
\hline \multirow{2}{*}{ Group Assessment } & Pre-test & 28 & 37.74 & 5.42 & \multirow{2}{*}{27} & \multirow{2}{*}{-11.062} & \multirow{2}{*}{$.000^{*}$} & \multirow{2}{*}{0.82} \\
\hline & Post-test & 28 & 49.15 & 3.09 & & & & \\
\hline \multirow{2}{*}{ Peer Assessment } & Pre-test & 31 & 35.95 & 4.04 & \multirow{2}{*}{30} & \multirow{2}{*}{-14.472} & \multirow{2}{*}{$.000^{*}$} & \multirow{2}{*}{0.87} \\
\hline & Post-test & 31 & 45.92 & 3.65 & & & & \\
\hline \multirow{2}{*}{ Researcher Assessment } & Pre-test & 31 & 31.35 & 6.23 & \multirow{2}{*}{30} & \multirow{2}{*}{-13.742} & \multirow{2}{*}{$.000 *$} & \multirow{2}{*}{0.86} \\
\hline & Post-test & 31 & 45.45 & 6.57 & & & & \\
\hline
\end{tabular}

$* p<.05$.

As seen in Table 5, it's procured that there is a significant difference between the pre-test and posttest as a result of self assessment, group assessment, peer assessment and researchers' assessments in terms of students' process skills $(p<.05)$. When the average marks of pre-application self assessment, group assessment, peer assessment and researchers' assessments pre-test are respectively 38.63, 37.74, 35.95 and 31.35; the average post-test marks are respectively 49.10, 49.15, 45.92 and 45.45. The acquired data shows that microteaching is effective on improving the process skills.

Table 6.

Observer Assessment-The Results of Wilcoxon Signed Rank Test.

\begin{tabular}{|c|c|c|c|c|c|c|}
\hline Teaching Experience & $\begin{array}{l}\text { Pre-Post } \\
\text { test }\end{array}$ & $\mathrm{N}$ & $\begin{array}{l}\text { Mean } \\
\text { rank }\end{array}$ & $\begin{array}{l}\text { Sum of } \\
\text { ranks }\end{array}$ & Z & $\mathrm{p}$ \\
\hline \multirow{2}{*}{$\begin{array}{l}\text { Communication Skills } \\
\text { Performance }\end{array}$} & $\begin{array}{l}\text { Negative } \\
\text { Ranks }\end{array}$ & 0 & .00 & .00 & \multirow{2}{*}{-3.066} & \multirow{2}{*}{$.002 *$} \\
\hline & $\begin{array}{l}\text { Positive } \\
\text { Ranks }\end{array}$ & 12 & 6.50 & 78.00 & & \\
\hline \multirow{2}{*}{ Illustrated Talk Performance } & $\begin{array}{l}\text { Negative } \\
\text { Ranks }\end{array}$ & 0 & .00 & .00 & \multirow{2}{*}{-3.061} & \multirow{2}{*}{$.002^{*}$} \\
\hline & $\begin{array}{l}\text { Positive } \\
\text { Ranks }\end{array}$ & 12 & 6.50 & 78.00 & & \\
\hline \multirow{2}{*}{$\begin{array}{l}\text { Process Skill Lesson } \\
\text { Performance }\end{array}$} & $\begin{array}{l}\text { Negative } \\
\text { Ranks }\end{array}$ & 1 & 1.00 & 1.00 & \multirow{2}{*}{-2.988} & \multirow{2}{*}{$.003^{*}$} \\
\hline & $\begin{array}{l}\text { Positive } \\
\text { Ranks }\end{array}$ & 11 & 7.00 & 77.00 & & \\
\hline
\end{tabular}

*. depends on negative order

Table 6 shows the results of the observer's assessment in terms of teaching skills of the pre-service teachers. According to these results, there is a statistically significant improvement in communication skills performance, illustrated talk performance, and process skill lesson performance after the microteaching. 


\section{Pre-service Chemistry Teachers' Self-Evaluations about Microteaching Applications}

Table 7 shows the results of self-evaluations of participants. The data gained from the written selfevaluations of the participants after the first and the last teachings were grouped in nine topics.

Table 7.

The Self-Evaluations by the Participants.

\begin{tabular}{|c|c|c|c|c|c|c|c|}
\hline \multirow{2}{*}{\multicolumn{2}{|c|}{ Self-evaluation topics }} & \multicolumn{3}{|c|}{ Pre \% } & \multicolumn{3}{|c|}{ Post \% } \\
\hline & & Adequate & Inadequate & None & Adequate & Inadequate & None \\
\hline 1 & Aware of the goal? & 85.19 & 11.11 & 3.7 & 100 & 0.00 & 0.00 \\
\hline 2 & $\begin{array}{l}\text { Aware of whether to manipulate } \\
\text { the process most properly or } \\
\text { fail? }\end{array}$ & 18.52 & 81.48 & 0.00 & 75.0 & 25.00 & 0.00 \\
\hline 3 & Assert the goal? & 25.93 & 74.07 & 0.00 & 71.43 & 28.57 & 0.00 \\
\hline 4 & $\begin{array}{l}\text { Aware of whether accomplish } \\
\text { his/her goal? }\end{array}$ & 59.26 & 40.74 & 0.00 & 89.29 & 10.71 & 0.00 \\
\hline 5 & $\begin{array}{l}\text { Assert the necessities of the } \\
\text { teaching approach? }\end{array}$ & 37.04 & 62.96 & 0.00 & 78.57 & 21.43 & 0.00 \\
\hline 6 & Good at time-management? & 14.82 & 81.48 & 3.70 & 78.57 & 21.43 & 0.00 \\
\hline 7 & $\begin{array}{l}\text { Give and take feedback during } \\
\text { the lesson }\end{array}$ & 11.12 & 44.44 & 44.44 & 60.71 & 39.29 & 0.00 \\
\hline 8 & Summarize the lesson & 0.00 & 22.22 & 77.78 & 64.29 & 35.71 & 0.00 \\
\hline 9 & $\begin{array}{l}\text { Assessment (using both the } \\
\text { traditional and the alternative } \\
\text { assessment techniques) }\end{array}$ & 25.92 & 37.04 & 37.04 & 82.14 & 17.86 & 0.00 \\
\hline
\end{tabular}

When the results of self-evaluation related to the students' first presentations are examined in Table 7 , it is certain that there is deficiency in some skills such as evaluation of the lesson, summing up the lesson, time management, asserting the goal. Observations during the lesson show that the participants are aware of the goals and that they know the steps of the teaching methods/approaches but have some difficulties in application especially to motivate, give feedbacks, evaluate and summarize the lesson. However, it is obvious that there are significant differences when the results of the selfevaluation related to the second presentations are examined. The skills such as summarizing the lesson, evaluating, using alternative evaluation techniques, giving and taking feedback during the lesson (increasing the communication) and managing the time effectively, improved greatly. While in the first presentations participants used only the traditional evaluation techniques (multiple choice, open ended questions), in the second presentations participants used both the traditional and the alternative evaluation techniques (puzzle, diagnostic tree and mind map) during and after the lesson.

Moreover, after first and last teachings the participants were asked for writing about 1) especially what they did well, 2) in which situations they could not help, 3) how they can improve the lesson, 4) a high school student is capable of understanding that lesson, for their feedback forms.

The analysis gained from the participants for the first question was like this: Whereas in the first presentations it is written that the best thing done is application of the teaching model/technique well (38.5\%), in the second presentation the best things done are application of the teaching approaches (54.8\%), motivating to join the lesson (90.3\%), using material/models (96.8\%), using both traditional and the alternative evaluation techniques and testing if the students know the most common misconceptions (96.8\%), summing up the lesson (93.5\%), associating with the daily life (96.8\%). For example, one of the participants stated her views for her second presentation: "I think I use the $5 E$ learning cycle as needed. I followed the steps of cycle...". Another participant stated his views after his second presentation: "I implemented argumentation. I believe that I have used the steps of argumentation well. I think it is better than my first presentation...". 
For the second question (in which situations they could not help), they stated that for their first presentation they could not help using models (90.3\%), asserting the wrong terms (93.5\%), evaluating and summing up the lesson (29\%), applying the teaching model/technique well $(67.7 \%)$, giving enough time to students for the hypothesis construction (16.1\%), drawing the attention of the students enough (16.1\%), making the students join the lesson (80.6\%), giving the worksheets (19.4\%), managing the classroom (12.9\%). For example, following statement shows one of the participants stated the problem for her first presentation, "I applied cooperative learning method for the first time, so there were deficiencies in implementing the method... I have not been able to apply what I want exactly". Another participant stated her views: "I felt that I could not draw the attention of the students enough...". And for their second presentations it is observed that the participants overcame the deficiencies seen in the first one.

For the third question, they stated that participants can improve the lesson by controlling the excitement $(87.1 \%)$, managing the time $(96.8 \%)$, using models $(87.1 \%)$, applying the teaching model well (83.9\%), making the students communicate and join the lesson (29\%), evaluating and summing up the lesson (32.2\%). One of the participants stated this situation, "The biggest obstacle to reach my target was my excitement... I could be better next time...". Another participant explained his views: "I did not enough time for evaluating students, because I could not use time effectively. In my second presentation, I will use time more effective and try to apply teaching method well". However, for their second presentations, participants overcame most of the deficiencies seen in the first presentation. One of the participants stated her views after her second presentation: "I realized what should I do and what not to do when I became a teacher through microteaching...". Also, it is showed that after second presentations, there is more advice such as using different types of questions in different cognitive levels, better associating with the daily life, giving longer periods of time when developing a hypothesis about the problem issues in students' minds, using common alternative terms to give examples that cause dilemmas in students' minds.

For the last question (a high school student is capable of understanding that lesson), while $45.2 \%$ of the participants stated that the high school students cannot understand the lesson taught by this teaching method for their first presentations, on the other hand 93.5\% the participants expressed that the lesson can be understood by the high school students in the second presentations.

When the effect of microteaching on chemistry teaching practice was examined in this study, it was observed that participants did not have enough preparation about the chemistry topics that they were going to teach in the first teaching; most of them gave the instruction keeping the lecture notes on hand and reading them. Also, the handling of subject was very superficial. In the second teaching practice, they did not keep the lecture notes on hand and rely on them less. Moreover, the handling of the subject was more detailed. Furthermore, in the first practice teaching, participants have less chemistry subject matter knowledge compared to their second practice teaching. Moreover science process skills such as making observation, drawing graphs, data recording, and data interpretation were more integrated in the second teaching practices of the participants. They emphasized the relationship between chemistry and daily life more and asked their students to interpret daily life situations in their second teaching practices.

While participants did not use both the name of the compounds according to the International Union of Pure and Applied Chemistry (IUPAC) rules and their widespread names in their first teachings, they used either of them in their second practice teaching. For example, they said "nitrogen hydrogen three" or "NH three" for $\mathrm{NH}_{3}$ in the first teaching practice, but in the second one they named $\mathrm{NH}_{3}$ as "Ammonia" or "Azane". In addition, in their first teachings, participants used expressions which may cause misconceptions, like "physical changes are reversible, chemical changes are irreversible", "chemical properties are related to the internal structure of matter, physical properties are related to the external structure of matter", "neutrons hit and swallow by uranium". However, these kind of expressions disappeared in the second teachings and they started to warn their students about common misconceptions in the literature. For example, one of the participants stressed the differences between 
dynamic and static equilibrium by explaining rope dancer's equilibrium. In addition, when writing the equation of a chemical reaction participant did not write the states of matters or balanced the chemical equation. They used letters A, B or C instead of using the formulas of real chemicals in their first teachings, but these deficiencies was not detected in their second teachings. In addition, it was observed that participants' instructions did not include the microscopic nature of chemistry in the first teachings; however, in their second teachings they emphasize the sub-microscopic structure of chemistry either verbally or by using drawings.

Finally, regarding these results, it is observed that the participants realized the deficiencies in their teaching skills and chemistry teaching practice and overcame them in their second teachings with the help of microteaching technique thanks to the researchers' and peers' feedbacks. In addition, it is observed that there have been improvements in terms of applying teaching models to their instruction, using different assessment techniques, being aware of students' alternative conceptions and managing the classroom during the process.

\section{Discussion \& Conclusion}

The aim of this research was to examine the effect of microteaching to the pre-service chemistry teachers' teaching experience (communication skills performance, illustrated talk performance, and process skill lesson performance). Microteaching gives an opportunity to the pre-service teachers to apply their teaching skills effectively. Thanks to this technique, the pre-service teachers encounter an atmosphere in which they improve their teaching skills by making use of the reflections of their mistakes (Amobi, 2005). In consideration of the data obtained from the research, it can be stated that microteaching is beneficial for improving the skills such as communication skills performance, illustrated talk performance, and process skill lesson performance. It is thought that the critics made by researchers and pre-service chemistry teachers' peers and observing their peers' teaching practices during microteaching process developed the pre-service chemistry teachers' awareness of their shortcomings. Then they tried to overcome their shortcomings by asking for help from researchers, doing some research on these shortcomings, learning from the critics made for their peers' teaching practices. It can be said that views from different sources about participants' teaching practice have influenced the development of pre-service chemistry teachers' teaching skills. The teacher roles undertaken by pre-service chemistry teachers help them to see their shortcomings which they didn't notice before. They didn't notice these shortcomings before, because they were students until the microteaching practices in Special Teaching Methods-II course. After microteaching practices they started to see themselves as teachers and criticize their peers looking through the window of a teacher.

As a result of the research, it is ascertained that microteaching helped the participants to improve their communication skills, make the students join the lesson, keep the students' interests alive and join the students in the process actively. It can be concluded that microteaching applications have a positive effect on improving student-related teaching skills of participants. It is thought that participants were more teacher-centered while they were planning their first presentations and therefore they did not focus on factors related to students. But through the effect of microteaching, they may have realized that these factors and begun to incorporate students to their teachings. Moreover, the results show that microteaching helped the development of the participants in some cases such as applying the teaching methods, using the evaluation techniques, motivating the students, managing the time effectively, associating the lesson with the daily life. These results of this research are parallel with the studies of Fernandez (2005), Mergler and Tangen (2010), Pauline (1993), and Sevim (2013).

At the end of the study, it is ascertained that there is an increase in pre-service chemistry teachers' process skill lesson performance intended for their performance during the lesson. In consideration of the data acquired from the self-evaluation forms of the participants; it is an incontestable reality that there is a significant difference between the first and the second presentations in terms of the skills intended for the course of the lesson. These findings have great similarities with the findings of BentonKupper (2001), which mean microteaching is beneficial for the processes of planning and applying the 
lesson. Moreover, the results revealed from self-evaluations of pre-service chemistry teachers show that participant encountered more problems in their first presentations, but in their second presentations they began to solve the problems they encounter and became more confident about teaching. It is thought that the awareness of them about their teaching is increased, because they have a chance to watch themselves while teaching. They began to think as a teacher and teach lesson more understandable for students. These results are similar with the studies of Cinici (2016), Karataş and Cengiz (2013).

Changing vision of the education system requires us to ensure that pre-service teachers have necessary pedagogical content knowledge and skills to be good teachers (Ravitch, 2007). Microteaching can be used to improve pre-service teachers' content knowledge, pedagogical content knowledge, general and personal teaching skills in teacher training programs (Klinzing \& Floden, 1991; Molina et al., 2011). The results of this study revealed that pre-service chemistry teachers became more aware of their shortcomings about chemistry and overcame these shortcomings via microteaching practices made in Special Teaching Methods-II course. It was found out that pre-service chemistry teachers improved their knowledge about chemistry topics, emphasized the relationship between chemistry and daily life more, became more aware of students' misconceptions and warned their students about common misconceptions in the literature, named of compounds according to IUPAC rules or widespread names, integrated science process skills in lessons more. Most of pre-service teachers have problems with content knowledge that they are going to teach in a conceptually rich or accurate manner (GessNewsome, 1999). Because of this reason, it is thought that pre-service chemistry teachers in this study had some challenges about chemistry knowledge. However, it was determined that pre-service chemistry teachers started to speak the language of chemistry due to microteaching. It is thought that microteaching practices provide an opportunity for pre-service chemistry teachers to inquiry themselves and realize their deficiencies about their content knowledge.

The goal of teacher education programs is to train effective and reflective teachers. Microteaching makes a big contribution to the development and enhancement of effective and reflective teachers and offers an opportunity to pre-service teachers to get essential training. Moreover, it helps pre-service teachers to be aware of what kind of a teacher they would like to be (Amobi \& Irwin, 2009; Bell, 2007; Benton-Kupper, 2001). There are several proofs that microteaching is an influential method which can be used to improve necessary teaching skills for an effective teaching life and carry out a critical analysis about their personal teaching styles (Amobi \& Irwin, 2009; Lu, Tsai \& Hong, 2008). Microteaching is a pedagogical approach so as to make studies about the pre-service teachers' courses, keep tracks of preservice teachers' progress and teach (Fernandez, 2010). Therefore, using microteaching which benefits pre-service teachers' teaching skills in teacher education programs and doing more studies which focuses on pre-service teachers' professional development are advised. Additionally for the future studies, it is thought that it will be useful to observe and compare the courses which are shaped by microteaching and traditional educational programs so as to confirm how microteaching was transferred to the teaching experiences. The future studies on microteaching will help the educators to comprehend pre-service teachers' experiences during the career development process (Fernandez, 2005). In this study, pre-service chemistry teachers did their presentations twice during microteaching applications. For future studies, it is recommended that pre-service teachers should do more presentations during microteaching and by this way; the amount of change in awareness of teaching skills may be examined. Moreover, it is recommended that there should be more researches about microteaching applications at different stages or courses of teacher training programs. Especially microteaching practices made in Special Teaching Methods-II course which contains the first teaching experiences of pre-service teachers are considered to be helpful to prepare them better for teaching profession. Moreover, microteaching practices in Teaching Experience course which consists of students in real classrooms may be more helpful to pre-service teaches. Thus, pre-service teachers will be offered a chance to put the theoretical knowledge into practice and realize their mistakes and correct them. 


\title{
Türkçe Sürümü
}

\begin{abstract}
Giriş
Öğrencilere verdiğimiz eğitimin kalitesi, öğretmenlerimizin niteliğine bağlıdır (Singh \& Sharma, 2004). Öğretmenlerimizin niteliği ise öğretmen eğitiminin niteliğine bağlıdır. Geçen 10 yıllık süreler boyunca öğretmen eğitimi programlarında çok çeşitli aktiviteler, etkinlikler ve stratejiler kullanılmıştır. Bunlardan bazıları gelip geçici olurken mikroöğretim içerikli olanlar, öğretmen eğitimi programlarında 21. yüzyılda hala güçlü ve canlı bir şekilde yer almaktadır (Benton-Kupper, 2001). Öğretmen adaylarına öğretimin ne anlama geldiği, etkili öğretim becerileri geliştirmeleri ve öğrencilerine nasıl daha faydalı olabilecekleri konularında yardımcı olabilecek en etkili yollardan biri mikroöğretimdir. Çünkü mikroöğretim tekniği öğretmen adaylarına derslerde gördükleri teorik bilgileri uygulama fırsatı vermektedir. Ayrıca, öğretim becerilerini, teorik bilgilerini ve öğretim stratejilerini harmanlamalarına olanak sağlamaktadır. Mikroöğretim öğretim faaliyetleriyle oldukça yakından ilişkilidir ve öğretmen eğitimi için de önemli bir tekniktir (Ambusaidi \& Al-Balushi, 2012; Amobi \& Irwin, 2009; Bell, 2007).
\end{abstract}

Mikroöğretim, 1960'lı yıllarda Stanford Üniversitesi öğretmen eğitimi programında geliştirilmiş ve öğrenci sayısının az olduğu bir sınıf ortamında uygulanmıştır (Allen, 1966). Stanford Üniversitesi'nde kullanılan mikroöğretim döngüsü; plan yapma, ders anlatma, gözlemleme ve eleştirilerde bulunma, dersi tekrar planlama, dersi tekrar anlatma, tekrar eleştirilerde bulunma ve yorum yapma basamaklarından oluşmaktadır (Brown, 1975; Pauline, 1993). 1960'lardan bu yana zaman içerisinde mikroöğretim uygulamalarına dönüt formları ve derslerin video ile kayıt altına alınması gibi çeşitli bileşenler eklenmiş ve bazı değişiklikler yapılmıştır. Ancak genel felsefesi aynı kalmıştır (Benton-Kupper, 2001). Öğretmen eğitiminde sıklıkla kullanılan mikroöğretim uygulamaları öğretmen adaylarının kendi uygulamaları hakkında bir öğretmen gibi düşünmelerini sağlamakta ve kendilerini eleştirmeleri için onları cesaretlendirmektedir (Donelly \& Fitzmaurice, 2011).

Zaman ve mekan açısından küçültülmüş gerçek bir öğrenme ortamına karşılık gelen mikroöğretim, öğretmen adaylarına bir sınıf ortamında deneme yapma ve performansı ile ilgili olarak dönüt alma fırsatı sağlamaktadır. Öğretmen eğitimi programlarında bu tekniğin kullanılması öğretmen adaylarının etkili öğretmenler olarak yetişmesine yardımcı olmaktadır (Benton-Kupper, 2001; Kpanja, 2001). Bu teknik sayesinde öğretmen adayları hem öğrenci hem de öğretmen rollerini üstlenerek farklı öğretim uygulamalarını deneyimleme şansına sahip olmakta ve gerçek bir öğretmen olmaya hazır hale gelmektedirler (Hu, 2008). Ayrıca sürecin kaydedilmesi dersten sonra özdeğerlendirme yapmaları için öğretmen adaylarına fırsat sağlamaktadır. Öğretmen adayları kendi derslerini ve akranlarının derslerini gözlemleyerek öğretim becerilerini ve kendilerine olan güvenlerini geliştirebilirler ve onlar için karmaşık olan öğretim sürecinde teori ile uygulama arasında bir köprü kurabilirler. Bu alanda yapılan çalışmalar öğretmen eğitiminde mikroöğretim tekniğinin kullanılmasının bir avantaj olduğunu ve bu tekniğin öğretmen eğitimi için önemli bir öğe olduğunu ortaya koymaktadır (Benton-Kupper, 2001; Subramaniam, 2006).

Bir öğretmen adayı göreve başlamadan önce yeterli tecrübeye sahip olabilecek şekilde, uygulamaya yönelik eğitim görmemişse; karşısına çıkabilecek tüm zorluklarla öğretmen olduğunda doğrudan yüz yüze gelmek zorunda kalmaktadır. Bu öğretmen adayı, öğretmen olup sınıfa girdiğinde titreyen bacaklarla, kalp çarpıntısı ile kendini derin sularda yüzüyor gibi hissederek eğitim vermek zorunda kalmaktadır (Singh \& Sharma, 2004). Mikroöğretim tekniği öğretmen adaylarının sınıf ortamında karşılaşabilecekleri güçlüklerin ve sorunların ortadan kaldırılmasına yardımcı olurken; aynı zamanda öğretmen adaylarının özgüvenlerinin artmasına da olanak sağlamaktadır (Brown, 1975). Öğretmen adaylarının öğretmenlik becerileri ile ilgili göreve başlamadan önce öğretmen adayları hakkında ipuçları elde etmek için mikroöğretim kullanılabilir. Bu teknik öğretmen adayının performansının gelişimi için bir önceki ders anlatımına göre bir sonraki ders anlatımındaki gelişmenin etkili bir şekilde görülebileceği bir 
unsurdur. Öğretme-tekrar öğretme yaklaşımı kullanılarak; öğretim becerileri daha iyi değerlendirilebilir, eleştiriler ve öneriler alınabilir. Tekrar öğretimde öğretmen adayı öğrencilerden gelen dönütler ve tepkiler doğrultusunda dersine yeni fikirlerle ve metotlarla devam edebilir. Mikroöğretimde öğretmen sınırlı sayıdaki öğrenci grubu ile farklı öğrenme-öğretme stratejilerini deneyebilir (Allen, 1966; Arsal, 2014; Bell, 2007; Benton-Kupper, 2001). Böylece çok fazla zaman harcamadan yeni metotları denemiş ve öğrencilerden dönüt almış olacaktır. Öğretmen adaylarının sunumundan sonra neyi iyi yaptığı ve hangi durumları nasıl daha iyi yapabileceği gibi bir dönüt alması öğretim sürecini yeniden yapılandırmasına yardımcı olur (Allen, 1966; Gee, 1992).

Diğer taraftan, mikroöğretimin olası negatif etkileri üzerindeki tartışmalar da hala devam etmektedir. Mikroöğretim ile ilgili yapılan eleştiriler, kontrollü sınıf ortamı nedeniyle öğretmen adaylarının gerçek sınıf ortamındaki problemlerle başa çıkamayacakları üzerinde yoğunlaşmaktadır (Cakir \& Aksan, 1992). Ayrıca akranların veya gözlemcinin eleştirileri ve video kameradan kaynaklanan heyecan da mikroöğretimin dezavantajları olarak bilinmektedir (Erokten \& Durkan, 2009). Buna rağmen sınıf ortamının oluşturulamadığı durumlarda mikroöğretim öğretmen adaylarının eğitimini daha kolay bir hale getirmektedir (Bakır, 2014). Mikroöğretime, öğretmen adaylarının kişiliğini bir gecede değiştirebilecek veya sınıflarda karşılaşabilecekleri bütün problemleri çözebilecek bir teknik olarak bakmamak gerekmektedir (Brown, 1975). Mikroöğretim öğretmen adaylarıı önbilgileri ve süreç içinde gelişen bilgi ve deneyimleri doğrultusunda yeni bağlantılar kurdukları, alan bilgilerini ve pedagojik alan bilgilerini geliştirmede onlara yardımcı olan bir süreçtir. Öğretmen adaylarına, akranları ve uzmanlar arasında, hata yapma ve bu hatalar üzerinde konuşma fırsatı sağlayan bir deneyimdir (Fernandez, 2005). Mikroöğretim uygulamaları öğretmen adaylarının zayıf ve güçlü yönleri ile ilgili pozitif duygular kazanmalarını sağlamaktadır. Bu uygulamalar sonucunda öğretmen adayları; öğrencileri derse motive edebilme, öğrenci seviyesine uygun davranabilme, öğrencilerin düşüncelerine yön verebilme, uygun metotları kullanabilme, dikkatini toplayabilme ve heyecanı ile başa çıkabilme konularında kendilerini daha yeterli hissetmektedir (Can, 2009).

Alanyazındaki çalışmalar mikroöğretimin öğretmen adaylarında, bir öğretmende olması beklenen davranışları arttırmada, alan bilgisini ve pedagojik alan bilgisini geliştirmede, teori ve uygulama arasında bağlantı kurmayı sağlamada, kaygı düzeylerini azaltmada önemli bir rol oynadığıı göstermektedir (Benton- Kupper, 2001; Darling-Hammond, Hammerness, Grossman, Rust \& Shulman, 2005; Fernandez, 2005; Fernandez \& Robinson, 2006; Kpanja, 2001; Mergler \& Tangen, 2010; Molina, Fernandez \& Nisbet, 2011; Pauline, 1993). Örneğin, Moline vd. (2011) mikroöğretimin ilköğretim matematik öğretmen adaylarının alan bilgisi ve pedagojik alan bilgisi üzerindeki etkisini incelediği çalışmada; mikroöğretimin öğretmen adaylarının alan bilgisi ve pedagojik alan bilgisini derinleştirmede etkili olduğu tespit edilmiştir. Fernandez (2010) matematik öğretmen adayları ile yürüttüğü çalışmada mikroöğretimin konu alan bilgisini ve konu alanını öğretmede farklı öğretim stratejileri kullanma becerilerini geliştirdiğini belirlemiştir. Mergler ve Tangen (2010) öğretmen adayı yeterlilikleri üzerinde mikroöğretim kullanımının etkisini incelemişlerdir. Mikroöğretimin öğretmen adaylarının öğretim bilgisi ve öğretmenlik mesleğine hazır bulunuşluğu açısından yeterlilik inançları üzerinde olumlu bir etkisi olduğunu tespit etmişlerdir. Fernandez (2005) mikroöğretimi kullanarak 36 matematik öğretmen adayı ile yürüttüğü çalışmada mikroöğretimin öğretmen adaylarının, başkalarının derslerini de analiz ederek, teori ile uygulama arasında bir bağ kurmasında ve konu alan bilgisini geliştirmede yardımcı olduğu sonucuna ulaşmıştır. Öğretmen adaylarının dersi planlaması, öğretim yapması, öğretimle ilgili yorumlar alması ve tekrar dersi planlamasıyla ilgili olan mikroöğretim çalışmalarının bir sonucu olarak; Benton-Kupper (2001), Fernandez ve Robinson (2006) öğretmen adaylarının mikroöğretimi zaman harcamaya değer faydalı bir öğretim deneyimi olarak tanımladıklarını belirtmişlerdir. Ayrıca öğretmen adayları akranlarından gelen dönütlerin kendi öğretim metotları üzerinde oldukça olumlu katkısı olduğunu ve akranlarının dersleri boyunca farklı öğretim metotlarını gözlemleme ve öğrenme şansını bulduklarını belirtmişlerdir. Kpanja (2001) ise mikroöğretim kullanımının öğretmen adaylarının öğretim becerilerini önemli ölçüde geliştirmede etkili olduğunu belirtmiştir. Benzer bir şekilde, Pauline (1993) mikroöğretimin, öğretim becerilerini geliştirmede başarılı bir şekilde kullanılabilecek bir teknik olduğunu ve çalışmasındaki öğretmenlerin \%91'inin mikroöğretimi faydalı veya çok faydalı olarak gördüklerini tespit etmiştir. Bakır (2014) fen bilgisi 
öğretmen adaylarıyla yürüttüğü çalışmada mikroöğretimin öğretim becerileri üzerindeki etkisini incelemiştir. Mikroöğretimin zaman yönetimi, planlama, etkili iletişim, sınıf yönetimi gibi öğretim becerileri üzerinde anlamlı bir etkisi olduğunu belirlemiştir. Cinici (2016) mikroöğretimin fen bilgisi öğretmen adaylarının özyeterlilik inançları üzerindeki etkisini araştırmıştır. Çalışmada fen bilgisi öğretmen adaylarının özyeterlilik inançlarını geliştirmede mikroöğretimin destekleyici bir araç olduğu belirlenmiştir. Karataş ve Cengiz (2016) kimya öğretmen adaylarının mikroöğretim deneyimleriyle ilgili görüşlerini incelemişlerdir. Çalışma sonucunda, kimya öğretmen adaylarının ilk anlatımlarında zaman yönetimi, planlama, kazanımları belirleme açısından problemler yaşadıklarını belirtikleri tespit edilmiştir. Ayrıca kimya öğretmen adayları öğretimle ilgili pek çok açıdan kendilerini değerlendirmede mikroöğretim metodunun kendilerine yardımcı olduğunu belirtmişlerdir.

Öğretmen adaylarının mesleki gelişimleri üzerinde mikroöğretim deneyimlerinin etkisini derinlemesine inceleyen çalışmalar, mikroöğretimin öğretmen eğitim programlarındaki potansiyel rolünü geliştirme açısından oldukça önem taşımaktadır (He \& Yan, 2011). Öğretmen adaylarına öğretimin ne anlama geldiği ve öğrencilerine nasıl daha faydalı olabilecekleri konusunda yardımcı olabilecek en etkili yollardan biri mikroöğretim olmasına rağmen, mikroöğretimin ne anlama geldiği konusu araştırmacılar tarafından yeterince incelenmemiştir (Bell, 2007). Ancak öğretmenin yaşayabileceği zorlukların üstesinden gelinebilmesi ve öğretmen adaylarının öğretim becerilerinin geliştirilebilmesi amacıyla, daha iyi öğretmenler yetiştirebilmek adına, gelişmekte olan öğretmen kimliği üzerinde olumlu etkisi olan mikroöğretim tekniğine öğretmen eğitim programlarında yer verilmesi gerektiği kaçınılmaz bir gerçek olarak karşımıza çıkmaktadır (Bell, 2007; Brown, 1975; Mergler \& Tangen, 2010; Singh \& Sharma, 2004).

Alanyazındaki çalışmalar incelendiğinde, öğretmen adaylarının mikroöğretimle ilgili görüşleri (Canbazoğlu Bilici \& Yamak, 2014; Demirbaş \& Afacan, 2013; Gürbüzoğlu Yalmancı \& Aydın, 2014; Karataş \& Cengiz, 2016; Sevim, 2013), öğretmen adaylarının sınıf yönetimi tutum ve inançlarına mikroöğretimin etkisi (Arsal, 2014), öğretmen adaylarının öğretim becerilerine mikroöğretimin etkisi (Bakır, 2014), mikroöğretimin öğretmen adaylarının konuşma becerisine etkisi (Bulut, Açık, \& Çiftçi, 2016), öğretmen adaylarının özyeterliliklerine mikroöğretimin etkisi (Cinici, 2016), mikroöğretimin öğretmen adaylarının bilgilerine etkisi (Fernandez, 2010; Molina et al., 2011), öğretmen adaylarının tutum ve davranışlarına mikroöğretimin etkisi (Uzun, Keleş, \& Sağlam, 2013) gibi farklı bağlamlarla ilgili çalışmaların yapıldığı görülmektedir. Bu çalışmada özel öğretim yöntemleri-Il dersi bağlamında mikroöğretim uygulamalarının iletişim becerileri performansı, gösterim ve sunum performansı ve dersle ilgili süreç becerisi performansı üzerindeki etkisi incelendi ve bu çalışma 14 hafta boyunca kimya öğretmen adaylarıyla yürütüldü. Ayrıca kimya öğretmen adaylarının mikroöğretim uygulamaları özdeğerlendirme, grup değerlendirme, akran değerlendirme, gözlemci ve araştırmacı değerlendirmeleri yapılarak incelendi. Böylece kimya öğretmen adaylarının mikroöğretim uygulamalarının farklı bakış açılarından değerlendirilmesi sağlandı. Bu çalışmada aşağıdaki araştırma sorularına cevap arandı:

- Kimya öğretmen adaylarının iletişim becerileri performansı, gösterim ve sunum performansı ve dersle ilgili süreç becerisi performansına mikroöğretimin etkisi nasıldır?

- Mikroöğretim boyunca kimya öğretmen adaylarının özdeğerlendirmeleri nasıldır?

\section{Yöntem}

\section{Araştırma Deseni}

Bu çalışmada tek grup ön test-son test deseni kullanıldı. Bu desende, tek bir grup için bir müdahaleden önce ve sonra bir ölçüm veya gözlem yapılmaktadır (Fraenkel, Wallen \& Hyun, 2012).

\section{Katılımcılar}

Bu çalışma Ankara'daki bir devlet üniversitesinde 2009-2010 eğitim öğretim yılı güz döneminde gerçekleştirildi. Çalışmaya beşinci sınıfta öğrenim gören, 19'u kız ve 12'si erkek toplam 31 kimya 
öğretmen adayı katıldı. Katılımcılar bir eğitim fakültesinin beş yıllık kimya eğitimi programında öğrenim görmekteydi. Çalışmanın katılımcıları uygun örnekleme yöntemi ile seçildi. Uygun örnekleme bazen araştırmacıların sahip olduğu tek seçenek olabilir. Bu durumda araştırmacı bu yöntemi kullanabilir, ancak araştırmacının örneklemi detaylı bir şekilde açıklaması gerekmektedir (Fraenkel et al., 2012). Çalışmanın yürütüldüğü dönemde Türkiye'de kimya öğretmenliği programı 10 yarıyıldan oluşmaktadır ve özel öğretim yöntemleri-ı ve okul deneyimi-I dersleri 8. yarıyılda, özel öğretim yöntemleri-Il ve okul deneyimiII dersleri 9. yarıyılda, Öğretmenlik Uygulaması dersi ise 10. yarıyılda alınmaktadır. Okul deneyimi-ı ve II derslerinde öğretmen adayları, danışman öğretmen tarafından kullanılan öğretim metotları, sınıftaki bir öğrenci, sınıf yönetimi, ders kitaplarının kullanımı, danışman öğretmen tarafından sorulan sorular gibi öğrenme ve öğretme süreçleriyle ilgili sadece gözlemler yapmaktadırlar. Mikroöğretim uygulaması öğretmen adayları tarafından okul deneyimi-ı dersi kapsamında yapılabilecek bir aktivitedir. Ancak danışman öğretmenler ve okul yöneticileri video kamera için izin vermedikleri için bu çalışmadaki kimya öğretmen adayları okul deneyimi-ı dersinde bu aktiviteyi yapmamışlardır. Öğretmenlik uygulaması dersi kapsamında ise öğretmen adayları öğretim uygulamaları yapmaktadır. Öğretmen adayları özel öğretim yöntemleri-ı dersinde kimya öğretiminde kullanılan farklı öğretim yaklaşımlarının, metotlarının ve tekniklerinin özelliklerinin farkına varmakta ve bunları özel öğretim yöntemleri-II dersinde farklı kimya konularına uygulamaktadırlar. Bu çalışma 9. yarıyılda verilen haftada dört saatlik özel öğretim yöntemleri-Il dersinde yürütüldü.

\section{Kullanılan Veri Toplama Araçları}

Bu çalışmada katılımcıların kendilerini ve arkadaşlarını değerlendirmesinde Pauline (1993) tarafından geliştirilen anket kullanıldı. Anket, katılımcılarıniletişim becerileri performansı, gösterim ve sunum performansı ve dersle ilgili süreç becerisi performansı ölçeklerinden oluşmaktadır. Mikroöğretim yaparken öğrencilere dönüt vermenin en iyi yolu ölçek kullanmaktır (Pauline, 1993). Anketin orijinal dili İngilizcedir. Öncelikle ölçek Türkçe'ye çevrildi ve dil geçerliği açısından bir Türk dili uzmanı tarafından kontrol edildi. Dil geçerliği sağlandıktan sonra anket, kapsam geçerliği açısından lisans ve lisansüstü düzeyde eğitim veren üç kimya eğitimi uzmanı tarafından kontrol edildi. Likert tipi beş seçenekli 50 maddeden oluşan anket katılımcıların becerilerindeki değişimi ortaya çıkarmak için kullanıldı. Anketteki bütün maddeler; hiç için 0 , zayıf için 1, orta için 2, iyi için 3 ve çok iyi için 4 şeklinde puanlandı. Kontrol listesinde iletişim becerileri performansı 19 maddeden, gösterim ve sunum performansı 17 maddeden ve dersle ilgili süreç becerisi performansı ise 14 maddeden oluşmaktadır. Kontrol listesinden alınabilecek puan 0 ile 200 arasında değişmektedir. İletişim becerileri performansı için örnek maddeler: "Öğretmen sesini ve tonlamasını iyi kullandı", "Öğretmen öğrencilerle yüksek düzeyde göz teması kurdu” şeklindedir. Gösterim ve sunum performansı için örnek maddeler: "Öğretmen öğrencilerin dikkatini çekti", "Öğretmen kullanacağı tüm materyalleri hazırlamıştı" şeklindedir. Dersle ilgili süreç becerisi performansı için örnek maddeler: "Öğretmen geçmiş derslerle ve gelecekteki derslerle bağlantı kurdu", "Öğretmen dersin kazanımlarını öğretti", "Öğretmen öğrencileri öğretilen kazanımlar açısından değerlendirdi" şeklindedir.

\section{Araştırma Süreci}

Bu çalışmada mikroöğretim uygulamaları 14 hafta boyunca özel öğretim yöntemleri-II dersi kapsamında yapıldı. Katılımcılar iletişim becerileri açısından; dersin içeriğinden çok öğretmenlik davranışları ve iletişim becerileri yönünden, gösterim ve sunum performansı açısından; dersin sunuş şekli yönünden ve dersle ilgili süreç becerisi performansı açısından; temel süreç becerileri ve üst düzey beceriler yönünden değerlendirildi. Ayrıca her katılımcı, kendi özdeğerlendirmesi, gözlemci, grup ve akranları tarafından değerlendirilirken bu değerlendirme ölçeğini kullanıldı. Bunun yanında dersi anlatan öğretmen adayı özdeğerlendirmesini yazılı olarak da sundu. Örümcek ağı diyagramı ise ilk anlatımlarında uygulanan tekniğin hangi aşamalarında daha iyi veya zayıf olduklarını görsel olarak görmelerini sağlamak için akranları tarafından süreç değerlendirme olarak kullanıldı. Araştırma süreci Tablo 1'de görülmektedir. 
Tablo 1.

Araştırma Süreci.

\begin{tabular}{ll}
\hline \multicolumn{2}{l}{ Araştırma sürecinin aşamaları } \\
\hline 1 & Katılımcılardan grupların oluşturulması \\
\hline 2 & Gruplar tarafından kullanılacak öğretim metotlarına karar verilmesi \\
\hline 3 & $\begin{array}{l}\text { Katılımcılar tarafından ders planlarının hazırlanması ve ders planlarıyla ilgili araştırmacıların } \\
\text { danışmanlık yapması }\end{array}$ \\
\hline 4 & Katılımcılar tarafından ilk sunumların yapılması (kamera ile kayıt altına alınması) \\
\hline 5 & $\begin{array}{l}\text { Kamera kayıtlarının sınıfta izlenmesi ve araştırmacılar, gözlemci ve akranlar tarafından } \\
\text { değerlendirme yapılması }\end{array}$ \\
\hline 6 & Sunum yapan katılımcının özdeğerlendirmesi \\
\hline 7 & Katılımcılar tarafından ikinci sunumların yapılması (kamera ile kayıt altına alınması) \\
\hline 8 & $\begin{array}{l}\text { Kamera kayıtlarının sınıfta izlenmesi ve araştırmacılar, gözlemci ve akranlar tarafından } \\
\text { değerlendirme yapılması }\end{array}$ \\
\hline 9 & Sunum yapan katılımcının özdeğerlendirmesi
\end{tabular}

Katılımcılardan kişi sayısı 2-4 arasında değişen 10 grup oluşturuldu. Her grup farklı bir öğretim tekniğini/modelini ortaöğretim kimya programından seçtikleri bir konudaki bir kavramı anlatmak için uyguladılar. Gruplar öncelikle seçtikleri öğretim tekniğini/modelini aşamalarına göre hangi aşamada hangi etkinliği kullanacaklarını belirleyerek bir plan hazırladı. Her bir gruptaki katılımcılar aynı öğretim metodunu kullandı, fakat sunumlarını farklı konularda bireysel olarak yaptılar. Böylece, katılımcılar farklı kişilerden on farklı öğretim metodunun uygulamasını görme şansına sahip oldular. Planlarını hazırlayan öğretmen adayları planları ile ilgili olarak araştırmacılar ile görüşerek dönüt aldılar. Daha sonra 10-15 dakikalık sürede bu dersleri sınıfta sundular. Fiziksel ve kimyasal değişimler, reaksiyon hızı, kimyasal denge, çözünürlüğe etki eden faktörler, asitlik kuvveti, ekzotermik ve endotermik reaksiyonlar ve elektrokimya katılımcıların mikroöğretim uygulamalarını gerçekleştirdikleri kimya konularıdır. Sunum sırasında akranlar uygulanmaya çalışılan öğretim tekniğinin/modelinin hangi aşamasında iyi, hangi aşamasında zayıf kaldığını ortaya koyan bir örümcek ağı diyagramı hazırlayarak geri dönüt sağladılar. Katılımcıların ders anlatım süreci kamera ile kayıt altına alındı. Sonra kaydedilen görüntüler sınıfta izlenirken katılımcılar, akranları ve araştırmacılar tarafından Pauline'nin (1993) geliştirdiği değerlendirme ölçeği kullanılarak değerlendirme yapıldı. Kayıtların izlenmesi tamamlandıktan sonra, özellikle öğretmen adayının neyi iyi yaptığı, hangi noktalarda eksik kaldığı, dersini nasıl geliştirebileceği, güçlü ve zayıf yönlerinin neler olduğu ile ilgili öğretmen adayının sınıf arkadaşlarından ve araştırmacılardan eleştiriler ve öneriler alındı. Ayrıca öğretmen adayının özdeğerlendirme yapabilmesi için öğretmen adayına fırsat tanındı.

Katılımcıların mikroöğretim uygulamaları boyunca, araştırmacılar hem gözlemci hem de değerlendirici olarak süreçte yer aldı. Katılımcılar mikroöğretim uygulamalarını yaparken araştırmacılar sınıftaydı ve katılımcıların öğretim uygulamalarını değerlendirdiler. Ayrıca katılımcılara karşılaştıkları zorlukları üstesinden gelme konusunda da yardımcı oldular. Örneğin katılımcılardan bazıları öğrencileri derse motive etmede problemler yaşadılar ve yardım istediler. Araştırmacılar bu katılımcıları günlük hayattan örnekler vermeye, ilginç bir hikaye anlatmaya, konularıyla ilgili rol oynamayı kullanmaya yönlendirdi. Ayrıca bazı katılımcılar muhtemel öğrenci yanlış kavramaları konusunda problemler yaşayıp yardım istediler. Bu durumda araştırmacılar katılımcıları kimyadaki yaygın öğrenci yanlış kavramaları ile ilgili kitapları, makaleleri ve tezleri okumaya yönlendirdi ve daha sonra katılımcılar bu yanlış kavramaların nedenleri ve giderilmesi hakkında araştırmacılarla görüştüler. Araştırmacıların değerlendirmesinin yanı sıra farklı katılımcılar tarafından gerçekleştirilen altı farklı ders için, araştırmacılar dışında altı farklı uzman tarafından, gözlemci değerlendirmesi yapıldı. Gözlemci değerlendirmesini yapan uzmanlardan ikisi kimya eğitiminde doktorasını tamamlamış, dördü ise kimya eğitiminde doktora öğrencisidir. 
Illk ders anlatımından sonra yapılan eleştiriler ve tavsiyeler doğrultusunda öğretmen adayının dersini tekrar planlayabilmesi için bir haftalık bir süre tanındı. Bu sürenin sonunda öğretmen adayı araştırmacılar ile görüşerek ders planını yeniden düzenledi. Yeniden hazırladığı dersi 10-15 dakikalık bir sürede tekrar anlattı. Anlatım kamerayla kayıt edildi. Kayıt tekrar izlenirken öğretmen adayı kendisini değerlendirirken, arkadaşları, araştırmacılar ve gözlemciler öğretmen adayını aynı değerlendirme ölçeğini kullanarak tekrar değerlendirdi. Kayıtların izlenmesinden sonra öğretmen neyi daha iyi yaptı, hangi noktalarda eksik kaldı ve bu dersi nasıl geliştirebilir gibi sorularla sınıftan yeniden dönütler alındı. Öğretmen adayı bu sürecin sonunda tekrar yazılı olarak iletişim becerileri performansı, gösterim ve sunum performansı ve dersle ilgili süreç becerisi performansı açılarından neleri daha iyi yaptığı veya hangi aşamalarda eksik olup olmadığıyla ilgili kendi özdeğerlendirmesini yaptı.

\section{Veri Analizi}

Bu çalışmada katılımcıların ilk ve son öğretimleri özdeğerlendirme, grup değerlendirmesi, akran değerlendirmesi ve araştırmacıların değerlendirilmesi yollarıyla değerlendirildi. Bu verilerin analizinde, bağımlı değişken aralık ölçeğinde olduğu ve normal dağılım gösterdiği için (Büyüköztürk, 2010), SPSS 15.0 programıyla ilişkili örneklemler için t-testi kullanıldı. Gözlemci değerlendirmelerinin analizinde, gözlem çiftleri birbirinden bağımsız olduğu için (Büyüköztürk, 2010), Wilcoxon işaretli sıralar testi kullanıldı. Ayrıca öğretmen adaylarının yazılı olarak verdikleri dönüt formu ve özdeğerlendirmelerinin analizinde ise betimsel analiz kullanıldı.

Verilerin analizinde tutarlık incelemesi için, farklı öğretim yaklaşımları kullanan, rastgele seçilen, altı katılımcının sunumları araştırmacılar ve üç kimya eğitimi uzmanı tarafından ayrı ayrı değerlendirildi. Araştırmacılar ve uzmanların değerlendirilmesi arasındaki tutarlık Kendall'ın uyum katsayısı ile hesaplandı ve 0.78 olarak tespit edildi. Araştırmacılar ve uzmanlar arasındaki görüş farklılıklarında uzlaşma sağlandıktan sonra değerlendirmeye araştırmacılar tarafından devam edildi.

\section{Sonuçlar}

\section{Kimya Öğretmen Adaylarının İletişim Becerileri Performansı, Gösterim Ve Sunum Performansı Ve Dersle ilgili Süreç Becerisi Performansı}

Çalışma sonucunda elde edilen verilere göre katılımcıların iletişim becerileri, gösterim ve sunum becerileri ve dersle ilgili süreç becerileri performanslarında gelişme olduğu belirlendi. Tablo 2'de katılımcıların öğretim deneyimleri becerilerine ilişkin bulguların ilişkili örneklemler için t-testi sonuçları görülmektedir.

Tablo 2.

Katılımcıların Öğretim Deneyimi Becerileri Açısından Ilişkili Örneklemler için T-Testi Sonuçları.

\begin{tabular}{|c|c|c|c|c|c|c|c|c|}
\hline Değerlendirme Türü & $\begin{array}{l}\text { Ön/son } \\
\text { test }\end{array}$ & $\mathrm{N}$ & $\bar{X}$ & $S$ & sd & $\mathrm{t}$ & $\mathrm{p}$ & $\eta 2$ \\
\hline \multirow{2}{*}{ Özdeğerlendirme } & Ön test & 30 & 146.17 & 19.43 & \multirow{2}{*}{29} & \multirow{2}{*}{-9.551} & \multirow{2}{*}{$.000^{*}$} & \multirow{2}{*}{0.76} \\
\hline & Son test & 30 & 176.47 & 13.15 & & & & \\
\hline \multirow{2}{*}{ Grup değerlendirmesi } & Ön test & 28 & 143.47 & 17.37 & \multirow{2}{*}{27} & \multirow{2}{*}{-11.330} & \multirow{2}{*}{$.000^{*}$} & \multirow{2}{*}{0.83} \\
\hline & Son test & 28 & 176.73 & 10.03 & & & & \\
\hline \multirow{2}{*}{ Akran değerlendirmesi } & Ön test & 31 & 135.30 & 13.58 & \multirow{2}{*}{30} & \multirow{2}{*}{-14.470} & \multirow{2}{*}{$.000 *$} & \multirow{2}{*}{0.87} \\
\hline & Son test & 31 & 164.65 & 12.18 & & & & \\
\hline \multirow{2}{*}{$\begin{array}{l}\text { Araştırmacı } \\
\text { değerlendirmesi }\end{array}$} & Ön test & 31 & 117.90 & 21.43 & \multirow{2}{*}{30} & \multirow{2}{*}{-12.425} & \multirow{2}{*}{$.000^{*}$} & \multirow{2}{*}{0.84} \\
\hline & Son test & 31 & 163.06 & 22.41 & & & & \\
\hline
\end{tabular}

$* p<.05$.

Tablo 2'de görüldüğü gibi öğrencilerin tüm beceriler açısından özdeğerlendirme, grup değerlendirmesi, akran değerlendirmesi ve araştırmacıların değerlendirmeleri sonucunda ön test ve son test puanları arasında anlamlı bir fark olduğu belirlendi $(p<.05)$. Uygulama öncesi özdeğerlendirme ön 
test ortalama puanı 146.17 iken; uygulama sonrası özdeğerlendirme son test ortalama puanın 176.47 olduğu tespit edildi. Uygulama öncesi grup değerlendirmesi ön test ortalama puanı 143.47 iken; uygulama sonrası grup değerlendirmesi son test ortalama puanın 176.73 olduğu belirlendi. Uygulama öncesi akran değerlendirmesi ön test ortalama puanı 135.30 iken; uygulama sonrası akran değerlendirmesi son test ortalama puan 164.65 olarak tespit edildi. Uygulama öncesi araştırmacıların değerlendirmesi ön test ortalama puanı 117.90 iken; uygulama sonrası araştırmacıların değerlendirmesi son test ortalama puanın 163.06 olduğu belirlendi. Elde edilen bu bulgular, katılımcıların öğretmenlik deneyimlerine, incelenen beceriler açısından, mikroöğretim tekniğinin istatistiksel olarak anlamlı ölçüde etkili olduğunu göstermektedir. Öğretmen adaylarının iletişim, gösterim ve sunum ve süreç becerilerini arttırmada mikroöğretim tekniğinin etkili olduğu anlaşılmaktadır. Mikroöğretim uygulaması sonucunda yapılan değerlendirmelerde; öğretmen adaylarının iletişim becerileri performansı açısından ders anlatırken ve soru sorarken sözlü ve sözlü olmayan iletişim becerilerinde ve öğretmenlik davranışlarında gelişmeler olduğu tespit edildi. Uygulama sonunda elde edilen veriler incelendiğinde; öğretmen adaylarının gösterim ve sunum performansı açısından derste kullandıkları sürece uygun yardımcı materyallerin çeşitliliğinde artış olduğu, derslerinde genel olarak tartışma yöntemiyle öğrencilerini derse aktif bir şekilde dahil ettikleri ve öğrencilerin ilgisini derse çekmede daha başarılı oldukları belirlendi. Öğretmen adaylarının dersle ilgili süreç becerisi performansı açısından; dersi, öğrencilerin aktif olarak katılabileceği, sorgulayarak öğrenecekleri ve sorularının cevaplarını kendilerinin keşfedecekleri bir ortamda gerçekleştirmede, öğrencilere gözlem yapma, sınıflama, ölçüm yapma, deney yapma becerilerini geliştirecek bir sınıf ortamı hazırlama becerilerinde gelişmeler olduğu tespit edildi.

Tablo 3.

Iletişim Becerileri Performansı Açısından Iliş̧kili Örneklemler için T-Testi Sonuçları.

\begin{tabular}{|c|c|c|c|c|c|c|c|c|}
\hline Değerlendirme Türü & $\begin{array}{l}\text { Ön/son } \\
\text { test }\end{array}$ & $\mathrm{N}$ & $\bar{X}$ & $\mathrm{~S}$ & sd & $\mathrm{t}$ & $\mathrm{p}$ & $\eta 2$ \\
\hline \multirow{2}{*}{ Özdeğerlendirme } & Ön test & 30 & 61.43 & 7.17 & \multirow{2}{*}{29} & \multirow{2}{*}{-5.346} & \multirow{2}{*}{$.000^{*}$} & 0.50 \\
\hline & Son test & 30 & 67.43 & 5.88 & & & & \\
\hline \multirow{2}{*}{ Grup değerlendirmesi } & Ön test & 28 & 60.87 & 5.83 & \multirow{2}{*}{27} & \multirow{2}{*}{-8.032} & \multirow{2}{*}{$.000^{*}$} & 0.74 \\
\hline & Son test & 28 & 67.52 & 4.34 & & & & \\
\hline \multirow{2}{*}{ Akran değerlendirmesi } & Ön test & 31 & 56.82 & 4.84 & \multirow{2}{*}{30} & \multirow{2}{*}{-9.881} & \multirow{2}{*}{$.000^{*}$} & 0.76 \\
\hline & Son test & 31 & 62.91 & 4.25 & & & & \\
\hline \multirow{2}{*}{$\begin{array}{l}\text { Araştırmacı } \\
\text { değerlendirmesi }\end{array}$} & Ön test & 31 & 50.35 & 9.083 & \multirow{2}{*}{30} & \multirow{2}{*}{-7.255} & \multirow{2}{*}{$.000^{*}$} & 0.64 \\
\hline & Son test & 31 & 62.06 & 9.164 & & & & \\
\hline
\end{tabular}

$* p<.05$.

Tablo 3 incelendiğinde; iletişim becerileri açısından özdeğerlendirme, grup değerlendirmesi, akran değerlendirmesi ve araştırmacıların değerlendirmeleri sonucunda ön test ve son test puanları arasında anlamlı bir fark olduğu tespit edildi $(p<.05)$. Iletişim becerileri açısından uygulama öncesi özdeğerlendirme, grup değerlendirmesi, akran değerlendirmesi ve araştırmacıların değerlendirmeleri ön test ortalama puanları sırasıyla $61.43,60.87,56.82$ ve 50.35 iken; son test ortalama puanları sırasıyla $67.43,67.52,62.91$ ve 62.06 olarak tespit edildi. Elde edilen bu bulgular, katılımcıların iletişim becerileri arttırmada mikroöğretim tekniğinin istatistiksel olarak anlamlı ölçüde etki ettiğini göstermektedir.

Tablo 4.

Gösterim ve Sunum Becerileri Açısından ilişskili Örneklemler Için T-Testi Sonuçları.

\begin{tabular}{|c|c|c|c|c|c|c|c|c|}
\hline Değerlendirme Türü & $\begin{array}{l}\text { Ön/son } \\
\text { test }\end{array}$ & $\mathrm{N}$ & $\bar{X}$ & $S$ & $\mathrm{sd}$ & $\mathrm{t}$ & $\mathrm{p}$ & $\eta 2$ \\
\hline \multirow{2}{*}{ Özdeğerlendirme } & Ön test & 30 & 46.10 & 8.36 & \multirow{2}{*}{29} & \multirow{2}{*}{-9.370} & \multirow{2}{*}{$.000 *$} & \multirow{2}{*}{0.75} \\
\hline & Son test & 30 & 59.93 & 4.44 & & & & \\
\hline \multirow{2}{*}{ Grup değerlendirmesi } & Ön test & 28 & 44.86 & 8.08 & \multirow{2}{*}{27} & \multirow{2}{*}{-10.398} & \multirow{2}{*}{$.000^{*}$} & \multirow{2}{*}{0.80} \\
\hline & Son test & 28 & 60.05 & 3.48 & & & & \\
\hline Akran değerlendirmesi & Ön test & 31 & 42.53 & 5.35 & 30 & -14.814 & $.000^{*}$ & 0.88 \\
\hline
\end{tabular}


Hüseyin AKKUŞ, Sinem ÜNER- Çukurova Üniversitesi Eğitim Fakültesi Dergisi, 46(1), 2017, 202-230

\begin{tabular}{lllllllll}
\hline & Son test & 31 & 55.83 & 4.53 & & & \\
\hline $\begin{array}{lllllllll}\text { Araştırmacı } \\
\text { değerlendirmesi }\end{array}$ & Ön test & 31 & 36.19 & 8.34 & \multirow{2}{*}{30} & \multirow{2}{*}{-12.463 } & \multirow{2}{*}{$000 *$} & \multirow{2}{*}{0.84} \\
\cline { 2 - 5 } & Son test & 31 & 55.54 & 7.70 & & & \\
\hline
\end{tabular}

$* p<.05$.

Tablo 4'te görüldüğü gibi; gösterim ve sunum becerileri açısından özdeğerlendirme, grup değerlendirmesi, akran değerlendirmesi ve araştırmacıların değerlendirmeleri sonucunda ön test ve son test puanları arasında anlamlı bir fark olduğu tespit edildi $(p<.05)$. Gösterim ve sunum becerileri açısından uygulama öncesi özdeğerlendirme, grup değerlendirmesi, akran değerlendirmesi ve araştırmacıların değerlendirmeleri ön test ortalama puanları sırasıyla 46.10, 44.86, 42.53 ve 36.19 iken; son test ortalama puanları sırasıyla 59.93, 60.05, 55.83 ve 55.54 olarak tespit edildi. Elde edilen bu bulgular, gösterim ve sunum becerilerinin arttırılmada mikroöğretim tekniğinin etkili olduğunu göstermektedir.

Tablo 5.

Dersle ilgili Süreç Becerisi Performansı Açısından Ilişskili Örneklemler Için T-Testi Sonuçları.

\begin{tabular}{|c|c|c|c|c|c|c|c|c|}
\hline Değerlendirme Türü & $\begin{array}{l}\text { Ön/son } \\
\text { test }\end{array}$ & $\mathrm{N}$ & $\bar{X}$ & $S$ & sd & $\mathrm{t}$ & $\mathrm{p}$ & $\eta 2$ \\
\hline \multirow{2}{*}{ Özdeğerlendirme } & Ön test & 30 & 38.63 & 6.17 & \multirow{2}{*}{29} & \multirow{2}{*}{-9.925} & \multirow{2}{*}{$.000 *$} & \multirow{2}{*}{0.77} \\
\hline & Son test & 30 & 49.10 & 3.82 & & & & \\
\hline \multirow{2}{*}{ Grup değerlendirmesi } & Ön test & 28 & 37.74 & 5.42 & \multirow{2}{*}{27} & \multirow{2}{*}{-11.062} & \multirow{2}{*}{$.000 *$} & \multirow{2}{*}{0.82} \\
\hline & Son test & 28 & 49.15 & 3.09 & & & & \\
\hline \multirow{2}{*}{ Akran değerlendirmesi } & Ön test & 31 & 35.95 & 4.04 & \multirow{2}{*}{30} & \multirow{2}{*}{-14.472} & \multirow{2}{*}{$.000 *$} & \multirow{2}{*}{0.87} \\
\hline & Son test & 31 & 45.92 & 3.65 & & & & \\
\hline \multirow{2}{*}{$\begin{array}{l}\text { Araştırmacı } \\
\text { değerlendirmesi }\end{array}$} & Ön test & 31 & 31.35 & 6.23 & \multirow{2}{*}{30} & \multirow{2}{*}{-13.742} & \multirow{2}{*}{$.000 *$} & \multirow{2}{*}{0.86} \\
\hline & Son test & 31 & 45.45 & 6.57 & & & & \\
\hline
\end{tabular}

$* p<.05$.

Tablo 5'de görülebileceği gibi; öğrencilerin süreç becerileri açısından özdeğerlendirme, grup değerlendirmesi, akran değerlendirmesi ve araştırmacıların değerlendirmeleri sonucunda ön test ve son test puanları arasında anlamlı bir fark olduğu tespit edildi $(p<.05)$. Süreç becerileri açısından uygulama öncesi özdeğerlendirme, grup değerlendirmesi, akran değerlendirmesi ve araştırmacıların değerlendirmeleri ön test ortalama puanları sırasıyla 38.63, 37.74, 35.95 ve 31.35 iken; son test ortalama puanları sırasıyla 49.10, 49.15, 45.92 ve 45.45 olarak tespit edildi. Elde edilen bu bulgular, süreç becerilerini arttırmada mikroöğretim tekniğinin anlamlı derecede etkili olduğunu göstermektedir.

Tablo 6.

Gözlemci Değerlendirmesi için Wilcoxon Iş̧aretli Sıralar Testi Sonuçları.

\begin{tabular}{|c|c|c|c|c|c|c|}
\hline Öğretimdeneyimi & Ön/son test & $\mathrm{n}$ & $\begin{array}{c}\text { Sıra } \\
\text { ortalaması }\end{array}$ & $\begin{array}{c}\text { Sıra } \\
\text { toplamı }\end{array}$ & $\mathrm{Z}$ & $\mathrm{p}$ \\
\hline \multirow{2}{*}{ İletişim becerileri performansı } & Negatif sıra & 0 & .00 & .00 & \multirow{2}{*}{-3.066} & \multirow{2}{*}{$.002 *$} \\
\hline & Pozitif sıra & 12 & 6.50 & 78.00 & & \\
\hline \multirow{2}{*}{$\begin{array}{l}\text { Gösterim ve sunum } \\
\text { performansı }\end{array}$} & Negatif sıra & 0 & .00 & .00 & \multirow{2}{*}{-3.061} & \multirow{2}{*}{$.002^{*}$} \\
\hline & Pozitif sıra & 12 & 6.50 & 78.00 & & \\
\hline \multirow{2}{*}{$\begin{array}{l}\text { Dersle ilgili süreç becerileri } \\
\text { performansı }\end{array}$} & Negatif sıra & 1 & 1.00 & 1.00 & \multirow{2}{*}{-2.988} & \multirow{2}{*}{$.003^{*}$} \\
\hline & Pozitif sıra & 11 & 7.00 & 77.00 & & \\
\hline
\end{tabular}

*. negatif sıralar temeline dayalı

Tablo 6 öğretmen adaylarının öğretmenlik becerileri açısından gözlemci değerlendirme sonuçlarını göstermektedir. Bu sonuçlara göre katılımcıların iletişim becerileri performansı, gösterim ve sunum 
performansı ve dersle ilgili süreç becerisi performansı açısından mikroöğretim uygulamalarından sonra istatistiksel olarak anlamlı bir fark olduğu görülmektedir.

\section{Kimya Öğretmen Adaylarının Mikroöğretim Uygulamalarıyla ilgili Özdeğerlendirmeleri}

Tablo 7 öğretmen adaylarının özdeğerlendirme sonuçlarını göstermektedir. Öğretmen adaylarının ilk ve son anlatımlarından sonra yazılı olarak alınan özdeğerlendirmelerinden elde edilen veriler analiz edilerek bulgular dokuz başıı altında gruplandırıldı.

Tablo 7.

Katılımcıların Özdeğerlendirmeleri.

\begin{tabular}{|c|c|c|c|c|c|c|}
\hline \multirow[t]{2}{*}{ Özdeğerlendirme başlıkarı } & \multicolumn{3}{|c|}{ Ön \% } & \multicolumn{3}{|c|}{ Son $\%$} \\
\hline & Yeterli & Yetersiz & Yok & Yeterli & Yetersiz & Yok \\
\hline 1 Amacının farkında mı? & 85.19 & 11.11 & 3.7 & 100 & 0.00 & 0.00 \\
\hline $\begin{array}{l}2 \text { Amacını ortaya koymak için en } \\
\text { uygun şekilde süreci yönlendirip } \\
\text { yönlendiremediğinin farkında } \\
\text { mı? }\end{array}$ & 18.52 & 81.48 & 0.00 & 75.0 & 25.00 & 0.00 \\
\hline 3 Amacını ortaya koyabildi mi? & 25.93 & 74.07 & 0.00 & 71.43 & 28.57 & 0.00 \\
\hline $\begin{array}{l}4 \text { Amaçlarının gerçekleştirip } \\
\text { gerçekleştiremediğinin farkında } \\
\text { mı? }\end{array}$ & 59.26 & 40.74 & 0.00 & 89.29 & 10.71 & 0.00 \\
\hline $\begin{array}{l}5 \text { Öğretim yaklaşımının } \\
\text { gerekliliklerini ortaya koyabildi } \\
\text { mi? }\end{array}$ & 37.04 & 62.96 & 0.00 & 78.57 & 21.43 & 0.00 \\
\hline 6 Süreyi etkin kullanabildi mi? & 14.82 & 81.48 & 3.70 & 78.57 & 21.43 & 0.00 \\
\hline 7 Derste, dönüt verme ve alma & 11.12 & 44.44 & 44.44 & 60.71 & 39.29 & 0.00 \\
\hline 8 Dersi özetleme & 0.00 & 22.22 & 77.78 & 64.29 & 35.71 & 0.00 \\
\hline $\begin{array}{l}\text { Değerlendirme yapma (Klasik } \\
\text { değerlendirmenin yanında } \\
\text { alternatif değerlendirme } \\
\text { tekniklerini kullanma) }\end{array}$ & 25.92 & 37.04 & 37.04 & 82.14 & 17.86 & 0.00 \\
\hline
\end{tabular}

Tablo 7'de öğrencilerin ilk anlatımlarıyla ilgili özdeğerlendirme sonuçlarına bakıldı̆̆ında; dersi değerlendirme, dersi özetleme, süreyi etkin kullanma, amacını ortaya koyma gibi becerilerin eksik olduğu görülmektedir. Derslerde yapılan gözlemlerde ise; öğretmen adaylarının amaçlarının farkında oldukları, öğretim yöntem/yaklaşımının basamaklarını bildiklerini ancak uygulamada sıkıntıları olduğu, özellikle güdüleme yapmada, sınıf içi dönütlerde, değerlendirme ve dersi özetlemede eksiklikleri olduğu araştırmacılar tarafından da tespit edildi. İkinci anlatımla ilgili özdeğerlendirme sonuçlarına bakıldığında büyük değişimlerin olduğu görülmektedir. Özellikle dersi özetleme, değerlendirme yapma ve alternatif değerlendirme tekniklerini kullanma, derste dönüt alma ve verme (iletişimin artması) ve süreyi etkin kullanma gibi becerilerde çok büyük değişme olduğu görülmektedir. Birinci anlatımlarında ders sonunda değerlendirme yapan öğretmen adaylarının büyük çoğunluğu yalnızca klasik değerlendirme tekniklerini (çoktan seçmeli, açık uçlu sorular) kullanırken, ikinci anlatımlarında tüm öğretmen adayları hem ders sonu değerlendirme hem de derste klasik değerlendirme tekniklerinin yanında alternatif değerlendirme tekniklerini (bulmaca, kavram haritası, tanılayıcı dallanmış ağaç vb.) kullandılar.

Ayrıca katılımcıların ilk anlatım ve son anlatımlarından sonra dönüt formlarında öğretmen adaylarının; 1) Özellikle neyi iyi yaptı, 2) Hangi durumlarda yardımcı olamadı, 3) Bu dersi nasıl geliştirebilir, 4) Lise öğrencisi bu dersi anlayabilir mi? soruları hakkındaki düşünceleri yazmaları istendi.

Katılımcılardan ilk soru için alınan verilerin analizine göre; öğretmen adayları özellikle neyi iyi yaptığı sorusuna, ilk anlatımlarında genellikle en iyi yapılanın öğretim model/tekniğini iyi uygulama (\%38.5) olarak belirtirken ikinci anlatımlarında ise öğretim yaklaşımını iyi uygulama (\%54.8), derse katılımı 
sağlama (\%90.3), materyal/model kullanma (\%96.8), dersi değerlendirmede klasik değerlendirmenin yanında alternatif değerlendirme tekniklerinin kullanılması ve yaygın alternatif kavramaların öğrencilerde var olup olmadığını test etme (\%96.8), dersi özetleme (\%93.5), günlük hayatla ilişkilendirme yapmalarının (\%96.8) iyi olduğunu ifade etmişlerdir. Örneğin bir katılımcı ikinci anlatımıyla ilgili görüşlerini şu şekilde ifade etmiştir: "5E öğrenme döngüsünü gerektiği gibi kullandığımı düşünüyorum. Döngünün basamaklarını takip ettim...". Bir başka katılımcı ise ikinci anlatımından sonra görüşlerini şu şekilde belirtmiştir: "Argümantasyonu uyguladım. Argümantasyonun basamaklarını iyi bir şekilde uyguladığıma inanıyorum. Illk anlatımımdan daha iyi olduğunu düşünüyorum...".

İkinci soru için (hangi durumlarda yardımcı olamadı), ilk anlatımları için model kullanma (\%90.3), alternatif kavramalarını ortaya koyma (\%93.5), değerlendirme ve dersi özetleme (\%29), öğretim teknik/modelini iyi uygulayama (\%67.7), derse girerken dikkat çekme (\%16.1), öğrencilerin derse katılımını sağlayama (\%80.6), sınıf hâkimiyeti (\%12.9) gibi durumlarda yardımcı olamadıklarını ifade ettiler. Örneğin, bir katılımcı ilk anlatımında yaşadığı problemi şu şekilde belirtmiştir: "İşbirlikli öğretim metodunu ilk defa uyguladım, o yüzden metodu uygulamada eksikliklerim oldu... İstediğimi tam olarak yapamadım". Bir başka katılımcı ise görüşlerini şöyle ifade etmiştir: "Öğrencilerin yeterince dikkatini çekemediğimi hissettim...". İkinci anlatımlarında ise birinci anlatımda görülen eksiklerin çoğunlukla giderildiği gözlendi.

Üçüncü soru için katılımcılar öğretmen adaylarının ilk anlatımlarında dersi geliştirebilmesi için ne yapabilir sorusuna; heyecanı yenme (\%87.1), süreyi iyi kullanma (\%96.8), model kullanması (\%87.1), öğretim yaklaşımını iyi uygulama (\%83.9), iletişim ve öğrencilerin derse katılımını sağlama (\%29) ve dersi değerlendirme ve dersi özetleme (\%32.2) yaparak geliştirebilir cevaplarını verdiler. Katılımcılardan biri bu durumu şu şekilde açıklamıştır: "Hedefime ulaşmadaki en büyük engel heyecanımdı... Bir sonrakinde daha iyi olabilirim...". Bir başka katılımcı ise görüşlerini şu şekilde açıklamıştır: "Öğrencileri değerlendirmek için yeterince zamanım kalmadı, çünkü zamanı etkili bir şekilde kullanamadım. ikinci anlatımımda zamanı daha etkili kullanacağım ve öğretim metodunu daha iyi uygulamaya çalışacağım". İkinci anlatımlarında ise ilk anlatımda görülen bu eksikliklerin büyük bir çoğunluğunun üstesinden geldiler. Bir katılımcı ikinci anlatımından sonra görüşlerini şu şekilde ifade etmiştir: "Mikroöğretimden sonra bir öğretmen olduğumda neyi yapmam ve neyi yapmamam gerektiğini fark ettim...". Ayrıca ikinci anlatımlardan sonra farklı soru tiplerinin kullanılması ve soruların farklı bilişsel düzeyde olması, günlük hayatla ilişkilendirmelerin daha iyi yapılması, hipotez oluşturulurken ayrılan zamanın biraz daha uzun tutulması, öğrenci zihinlerinde bilişsel çelişki yaratan örneklerin verilmesi ve bunun için yaygın alternatif kavramaların daha çok kullanılması gibi önerilerin geldiği gözlendi.

Son soru için (lise öğrencileri bu dersi anlayabilir mi) sorusuna, ilk anlatımlarında katılımcıların $\% 45,2$ 'si lise öğrencilerinin bu anlatım tarzı ile bu dersi anlamayacağını ifade ederken, ikinci anlatımlarında öğretmen adaylarının \%93,5’i dersin lise öğrencileri tarafından anlaşılabileceğini ifade ettiler.

Kimyadaki kavramların öğretimine mikroöğretimin etkisi incelendiğinde; katılımcıların anlatacakları kimya konularına ilk anlatımlarında yeterli hazırlıklarının olmadığı, katılımcıların pek çoğunun öğretim sırasında elinde ders notlarının bulunduğu ve notları okudukları gözlemlendi. Ayrıca konunun ele alınış şeklinin oldukça yüzeysel olduğu belirlendi. İkinci anlatımlarda ise ellerinde ders notları yoktu ve notlara daha az güvendiler. Ayrıca konuları daha derinlemesine ele aldılar. Bunun yanı sıra ilk anlatımlarında konu alan bilgisi açısından daha zayıf oldukları belirlendi. Ayrıca gözlem yapma, grafik çizme, veri kaydetme ve verileri yorumlama gibi bilimsel süreç becerilerinin ikinci anlatımlarda katılımcılar tarafından daha fazla derse dahil edildiği tespit edildi. İkinci anlatımlarda katılımcıların kimya ile günlük hayat bağlantısını kurdukları ve günlük hayatla ilgili durumları öğrencilerinin yorumlamasını istedikleri belirlendi.

Katılımcıların ilk anlatımlarında kimyasal maddelerin adını Uluslararası Temel ve Uygulamalı Kimya Birliği [International Union of Pure and Applied Chemistry (IUPAC)] kurallarına veya yaygın kullanımlarına uygun bir şekilde okumadıkları, aynen yazıldığı şekliyle okudukları; ikinci anlatımlarında 
ise bu hususa özen gösterdikleri belirlenmiştir. Örneğin ilk anlatımlarında $\mathrm{NH}_{3}$ için "azot hidrojen üç" veya "enhaş üç", ikinci anlatımlarında ise "amonyak" veya "azan" demişlerdir. Ayrıca katılımcıların ilk anlatımlarında alternatif kavramaya sebep olabilecek ifadeler kullandıkları, ancak ikinci anlatımlarında bu duruma yol açmayacak şekilde davrandıkları belirlenmiştir. Örneğin ilk anlatımlarında fiziksel/ kimyasal değişim ile ilgili "kimyasal değişimler geri dönüşümsüzdür", kimyasal denge ile ilgili "denge reaksiyonları tersinirdir, diğer reaksiyonlar tersinir değildir", karışımların ayrılması ile ilgili "maddenin içyapısı ile ilgili özellikler kimyasal özellikler, dış yapısı ile ilgili özellikler fiziksel özelliklerdir", radyoaktivite ile ilgili "nötron çarpıp uranyum içinde yutuluyor" ifadelerini kullanmıştır. İkinci anlatımlarında ise alternatif kavramalara yol açacak bu ifadeleri kullanmadıkları ve alanyazındaki yaygın alternatif kavramalarla ilgili öğrencileri uyarmaya başladıkları belirlenmiştir. Örneğin denge ile ilgili anlatım yapan katılımcı ip cambazı örneğini kullanarak kimyasal dengenin, cambazın ip üzerindeki statik dengesinden farklı olduğunu, statik değil dinamik denge olduğunu vurgulamıştır. Öğretmen adaylarının ilk anlatımlarında kimyasal eşitlikleri yazarken maddelerin fiziksel hallerini yazmadıkları, kimyasal eşitlikleri denkleştirmedikleri tespit edildi. Gerçek kimyasal maddeler kullanmak yerine "A, B, C gibi" ifadeler kullandıkları belirlenirken; ikinci anlatımlarda bu durumların ortadan kalktığı belirlenmiştir. Öğretmen adaylarının ilk anlatımlarında kimyanın mikroskobik doğasına hiç değinmedikleri, ikinci anlatımlarında ise mikroskobik düzeyde çizimler yaparak veya bu çizimleri göstererek konular ile ilgili açıklamalar yaptıkları tespit edilmiştir.

Sonuç olarak; araştırmanın bulguları göz önünde bulundurulduğunda, mikroöğretim tekniği yardımıyla, akranların ve araştırmacıların dönütleri sayesinde katılımcıların öğretim becerilerindeki ve kimya öğretimindeki eksikliklerini fark ettikleri ve ikinci anlatımlarında bu eksikliklerinin üstesinden geldikleri gözlemlendi. Ayrıca süreç boyunca öğretim sırasında öğretim modelini uygulama, farklı değerlendirme tekniklerini kullanma, öğrenci alternatif kavramalarının farkına varma ve sınıf yönetimi açılarından gelişmeler olduğu belirlendi.

\section{Tartışma ve Öneriler}

$\mathrm{Bu}$ araştırmanın amacı, kimya öğretmen adaylarının öğretim deneyimlerine (iletişim becerileri performansı, gösterim ve sunum performansı ve dersle ilgili süreç becerisi performansı) mikroöğretim tekniğinin katkısını incelemektir. Mikroöğretim, öğretim becerilerini etkili bir şekilde uygulamaları için öğretmen adaylarına fırsat sunmaktadır. Bu teknik sayesinde öğretmen adayları, yaptıkları hataların yansıması yoluyla bu hatalardan yararlanarak; öğretmenlik becerilerini geliştirebildikleri bir ortamla karşı karşıya kalmaktadır (Amobi, 2005). Bu çalışmadan elde edilen bulgular ışığında; mikro öğretim tekniğinin öğretmen adaylarının iletişim becerileri performansı, gösterim ve sunum performansı ve dersle ilgili süreç becerisi performansının gelişmesinde katkı sağladığı görülmektedir. Mikroöğretim süreci boyunca araştırmacılar ve kimya öğretmen adayının akranları tarafından yapılan değerlendirmelerin ve akranlarının öğretim uygulamalarını gözlemlemelerinin kimya öğretmen adaylarının eksiklikleri ile ilgili farkındalıklarını geliştirdiği düşünülmektedir. Böylece katılımcılar eksikliklerinin üstesinden gelebilmek için araştırmacılardan yardım isteyerek, eksiklikleri ile ilgili araştırmalar yaparak, akranlarının öğretim uygulamasına yapılan eleştirilerden faydalanarak eksikliklerinin üstesinden gelmeye çalışmışlardır. Katılımcıların öğretim uygulaması ile ilgili farklı kaynaklardan alınan görüşlerin kimya öğretmen adaylarının öğretim becerilerinin gelişimini etkilediği söylenebilir. Kimya öğretmen adaylarının üstlendikleri öğretmen rolleri daha önce fark etmedikleri eksikliklerini fark etmelerinde onlara yardımcı oldu. Katılımcılar bu eksikliklerini daha önce fark etmediler, çünkü özel öğretim yöntemleri-II dersindeki mikroöğretim uygulamalarına kadar hep öğrenciydiler. Mikroöğretim uygulamalarından sonra kendilerini öğretmen olarak görmeye başladıkları ve akranlarını eleştirirken bir öğretmenin bakış açısı ile eleştirdikleri düşünülmektedir.

Çalışmanın sonucunda, mikroöğretim uygulamasının öğretmen adaylarının iletişim becerilerinde, öğrencileri ders sürecine dahil etmede, öğrencilerin ilgisini canlı tutmada ve öğrencileri aktif olarak sürece katmada gelişmeler gösterdikleri tespit edildi. Mikroöğretim uygulamalarının katılımcıların öğrencilerle ilgili öğretim becerilerini geliştirmede pozitif bir etkisi olduğu yorumu yapılabilir. Katılımcıların ilk anlatımlarını planlarken öğretmen merkezli oldukları ve bu nedenle öğrencilerle ilgili 
faktörleri göz önünde bulundurmadıkları düşünülmektedir. Fakat mikroöğretimin etkisi sayesinde katılımcılar bu faktörlerin farkına vardılar ve öğretimlerine öğrencileri de dahil etmeye başladılar. Ayrıca ilk ders anlatımlarından ve ikinci ders anlatımlarından sonra öğretmen adaylarından alınan dönüt formlarından elde edilen veriler; mikroöğretim tekniğinin öğretim yöntemlerini uygulama, değerlendirme tekniklerini kullanma, öğrencileri derse güdüleme, ders süresini etkin bir şekilde kullanma, dersin günlük hayatla ilişkilendirilmesi konularında öğretmen adaylarının gelişimine yardımcı olduğunu göstermektedir. Çalışmanın bu bulguları Fernandez (2005), Mergler ve Tangen (2010), Pauline (1993) ve Sevim (2013) tarafından yürütülen çalışmaların sonuçlarıyla benzerlik göstermektedir.

Bu çalışmanın sonucunda kimya öğretmen adaylarının dersteki performanslarına yönelik olan dersle ilgili süreç becerisi performanslarında artış olduğu tespit edildi. Ayrıca katılımcıların özdeğerlendirmesinden elde edilen veriler sonucunda; katılımcıların, dersin sürecine yönelik beceriler açısından, ilk anlatımları ve ikinci anlatımları arasında anlamlı değişimler olduğu tespit edildi. Çalışmanın bu bulguları; Benton-Kupper'in (2001) çalışmasının sonucunda derslerin planlanması ve uygulanması ile ilgili mikroöğretimin çok yararlı olduğu yönünde görüş bildiren öğretmen adaylarının düşünceleri ile uyum içindedir. Ayrıca kimya öğretmen adaylarının özdeğerlendirmelerinden elde edilen sonuçlar; katılımcıların ilk anlatımlarında daha fazla problemle karşılaştıklarını, fakat ikinci anlatımlarında problemleri çözmeye başladıklarını ve öğretimle ilgili daha özgüvenli hale geldiklerini göstermektedir. Katılımcıların öğretim yaparken kendilerini izleme şansı olduğu için öğretimleri ile ilgili farkındalıklarının arttığı düşünülmektedir. Bir öğretmen gibi düşünmeye ve öğrenciler için daha anlaşılır ders anlatmaya başladıkları söylenebilir. Çalışmanın bu sonuçları Cinici (2016), Karataş ve Cengiz (2013) tarafından yapılan çalışmaların sonuçlarıyla da benzerlik göstermektedir.

Eğitimin değişen vizyonu bugün öğretmen adaylarımızın gerekli bilgi ve becerilere sahip öğretmenler olarak yetiştiğinden emin olmamızı gerektirmektedir (Ravitch, 2007). Mikroöğretim, öğretmen eğitimi programlarında öğretmen adaylarının alan bilgilerinin, pedagojik alan bilgilerinin, genel ve bireysel öğretim becerilerinin gelişimini sağlamak için kullanılabilir (Klinzing \& Floden, 1991; Molina et al., 2011). Çalışmanın sonuçları özel öğretim yöntemleri-II dersinden yapılan mikroöğretim uygulamaları aracılığıyla kimya öğretmen adaylarının kimya ile ilgili eksikliklerini daha çok fark ettiklerini ortaya çıkarmaktadır. Kimya öğretmen adaylarının kimya konularıyla ilgili bilgilerini geliştirdikleri, kimya ve günlük hayat bağlantısına daha çok vurgu yaptıkları, öğrenci alternatif kavramalarının daha çok farkına vardıkları ve öğrencileri alanyazındaki yaygın alternatif kavramalarla ilgili uyardıkları, bileşiklerin adlandırılmasında IUPAC kurallarını veya yaygın adları kullandıkları, bilimsel süreç becerilerini derslerine daha fazla dahil ettikleri tespit edildi. Birçok öğretmen adayı öğretecekleri alan bilgisini kavramsal olarak zengin bir biçimde öğretmekle ilgili problemler yaşamaktadır (Gess-Newsome, 1999). Bu nedenle bu çalışmadaki kimya öğretmen adaylarının kimya bilgisiyle ilgili bazı zorluklar yaşadıkları düşünülmektedir. Bununla birlikte mikroöğretim sayesinde kimya öğretmen adaylarının kimyanın dilini konuşmaya başladıkları tespit edildi. Mikroöğretim uygulamalarının kimya öğretmen adaylarına alan bilgileri konusunda kendileri sorgulama ve eksikliklerini fark etmeleri için fırsat sağladığı düşünülmektedir.

Öğretmen eğitimi programlarının hedefi etkili öğretmenler yetiştirmektir. Etkili öğretmenler yetiştirmede ve geliştirmede mikroöğretimin oldukça büyük bir katkısı bulunmaktadır ve öğretmen adaylarına gerekli eğitimi almaları için fırsat tanımaktadır. Ayrıca öğretmen adaylarına nasıl bir öğretmen olmak istediklerini anlamada da yardımcı olmaktadır (Amobi \& Irwin, 2009; Bell, 2007; Benton-Kupper, 2001). Mikro öğretimin öğretmen adaylarının etkili bir eğitim için gerekli öğretmenlik becerilerini geliştirmek ve kendi öğretim stilleri ile ilgili eleştirel bir analiz yapmak amacıyla kullanılabilecek etkili bir metot olduğuna dair pek çok kanıt bulunmaktadır (Amobi \& Irwin, 2009; Lu, Tsai \& Hong, 2008). Mikroöğretim tekniği ile öğretmen adaylarının derslerine yönelik çalışmalar yapmak, öğretmen adaylarının gelişimini ve öğrenimini takip etmek amacıyla kullanılabilecek pedagojik bir yaklaşımdır (Fernandez, 2010). Bu nedenle öğretmen adaylarının becerilerinin gelişmesine yardımcı olan mikroöğretim tekniğinin öğretmen eğitimi programlarında kullanılması ve öğretmen adaylarının mesleki gelişimlerine ve öğretmenlik becerilerine etkisini araştıran daha fazla çalışmanın yapılması önerilmektedir. Ayrıca ilerde yapılacak çalışmalarda; mikroöğretim tekniğinin öğretmenlik yaşantılarına 
nasıl transfer edildiğini tespit etmek için mikroöğretim tekniğinin kullanıldığı ve kullanılmadığı öğretim programları ile yetişen öğretmen adaylarının, gerçek sınıf ortamında, öğretmen olduktan sonra derslerinin izlenmesinin ve karşılaştırılmasının alana katkı sağlayabileceği düşünülmektedir. Mikroöğretim tekniği ile ilgili gelecekte yapılacak çalışmalar eğitimcilere; öğretmenlerin mesleki gelişim süreci içindeki deneyimlerini anlamada yardımcı olacaktır (Fernandez, 2005). Bu çalışmada mikroöğretim uygulamaları boyunca kimya öğretmen adayları iki defa anlatım yaptılar. Gelecekteki çalışmalarda, öğretmen adaylarının mikroöğretim süresince daha fazla anlatım yapması ve bu yolla öğretim becerilerindeki değişim farkındalığının miktarının araştırılması önerilmektedir. Ayrıca öğretmen eğitim programlarının farklı aşamalarında veya derslerinde mikroöğretim uygulamalarıyla ilgili daha fazla çalışma yapılması önerilmektedir. Özellikle öğretmen adaylarının ilk öğretmenlik deneyimlerini yaşadığı özel öğretim yöntemleri-II dersinde yapılan mikroöğretim uygulamalarının öğretmen adaylarını mesleğe hazırlamada etkili olabileceği düşünülmektedir. Ayrıca Öğretmenlik uygulaması dersinde yapılacak mikroöğretim uygulamalarının gerçek sınıf ortamındaki öğrencileri kapsadığı için öğretmen adaylarına daha faydalı olabilir. Böylece öğretmen adayları teorik bilgilerini uygulamaya geçirebilirler, yanlışlarını fark eder ve düzeltebilirler. 


\section{References}

Allen, D. W. (1966). Micro-teaching: A new framework for in-service education. The High School Journal, 49, 355-362. Retrieved from ERIC database. (ED013240).

Ambusaidi, A. K., \& Al-Balushi, S. M. (2012). A longitudinal study to identify prospective science teachers' beliefs about science teaching using the draw-a-science-teacher-test checklist. International Journal of Environmental \& Science Education, 7(2), 291-311. Retrieved from http://www.ijese.com/IJESE_v7n2_Ambusaidi-and-Al-Balushi.pdf

Amobi, F. A., \& Irwin, L. (2009). Implementing on-campus microteaching to elicit preservice teachers' reflection on teaching actions: Fresh perspective on an established practice. Teacher Education Quarterly, 32, 115-130. Retrieved from ERIC database. (EJ854876)

Amobi, F. A. (2005). Preservice teachers' reflectivity on the sequence and consequences of teaching actions in a microteaching experience. Journal of the Scholarship of Teaching and Learning, 9(1), 2734. Retrieved from ERIC database. (EJ795309).

Arsal, Z. (2014). Mikro öğretimin öğretmen adaylarının sınıf yönetimi tutum ve inançlarına etkisi. Mersin Üniversitesi Eğitim Fakültesi Dergisi, 10(3), 137-150.

Bakır, S. (2014). The effect of microteaching on the teaching skills of pre-service science teachers. Journal of Baltic Science Education, 13(6). 789-801.

Bell, N. D. (2007). Microteaching: What is it that is going on here?. Linguistics and Education, 18, 24-40. doi:10.1016/j.linged.2007.04.002

Benton-Kupper, J. (2001). The microteaching experience: Student perspectives. Education, 121(4), 830835.

Brown, G. (1975). Microteaching a programme of teaching skills. London: Methuen.

Bulut, K., Açık, F., \& Çiftçi, Ö. (2016). Mikro öğretim tekniğinin Türkçe öğretmen adaylarının konuşma becerilerine etkisi. Ana Dili Eğitimi Dergisi, 4(1), 134-150.

Büyüköztürk, Ş. (2010). Sosyal bilimler için very analizi el kitabı: istatistik, araştırma deseni, SPSS uygulamaları ve yorum. (11. Baskı). Ankara: Pegem Akademi.

Cakir, O., \& Aksan, Y. (1992). Yabancı dil öğretmeni yetiştirmede mikro öğretimin rolü: Bir model. Hacettepe Üniversitesi Eğitim Fakültesi Dergisi, 7, 313-320.

Can, V. (2009). A microteaching application on a teaching practice course. Cypriot Journal of Educational Sciences, 4, 125-140. Retrieved from http://www.world-educationcenter.org/index.php/cjes/article/viewFile/111/44

Canbazoğlu Bilici, S., \& Yamak, H. (2014). Teknolojik pedagojik alan bilgisi temelli bir araştırmada öğretmen adaylarının mikroöğretim hakkındaki görüşleri. Mehmet Akif Ersoy Üniversitesi Eğitim Fakültesi Dergisi, 32, 40-61.

Cinici, A. (2016). Pre-service teachers' science teaching self-efficacy beliefs: the influence of a collaborative peer microteaching program. Mentoring \& Tutoring: Partnership in Learning, 24(3), 228-249. doi: 10.1080/13611267.2016.1222812

Darling-Hammond, L., Hammerness, K., Grossman, P., Rust, F., \& Shulman, L. (2005). The design of teacher education programs. In L. Darling-Hammond and J. Bransford (Eds.), Preparing teachers for $a$ changing world: What teachers should learn and be able to do (pp. 391-441). San Francisco: JosseyBass.

Demirbaş, M., \& Afacan, Ö. (2013). The views of prospective classroom teachers on interactive microteaching applications about science. Balkan Physics Letters, 21, 21-28.

Donnelly, R., \& Fitzmaurice, M. (2011). Towards productive reflective practice in microteaching. Innovations in Education and Training International, 48(3), 335-346. 
Erokten, S., \& Durkan, N. (2009). Özel öğretim yöntemleri Il dersinde mikro öğretim uygulamaları. Paper presented at the 1st International Congress of Educational Research, Çanakkale, Türkiye.

Fernandez, M. L. (2010). Investigating how and what prospective teachers learn through microteaching lesson study. Teaching and Teacher Education, 26, 351-362. doi:10.1016/j.tate.2009.09.012

Fernandez, M. L. (2005). Learning through microteaching lesson study in teacher preparation. Action in Teacher Education, 26(4), 37-47. doi:10.1080/01626620.2005.10463341

Fernandez, M. L., \& Robinson, M. (2006). Prospective teachers' perspectives on microteaching lesson study. Education, 127(2), 203-215. Retrieved from http://ehis.ebscohost.com/ehost/pdfviewer/pdfviewer?sid=5fb24c52-e5c0-4d83-84d2303884f7f243\%40sessionmgr10\&vid=5\&hid=7

Fraenkel, J. R., Wallen, N. E., \& Hyun, H. H. (2012). How to design and evaluate research in education. (8th Edition). New York: McGraw-Hill.

Gee, J. B. (1992). Innovation in instructional strategies used with graduate students enrolled in an advanced heterogeneous methods class. Paper presented at the Annual Meeting of the Mid-South Educational Research Association, Knoxville.

Gess-Newsome, J. (1999). Secondary teachers' knowledge and beliefs about subject matter and their impact on instruction. In J. Gess-Newsome \& N. G. Lederman (Eds.), Examining pedagogical content knowledge (pp. 51-94). Dordrecht, The Netherlands: Kluwer Academic Publishers.

Gürbüzoğlu Yalmancı, S., \& Aydın, S. (2014). The views of Turkish pre-service science teachers concerning microteaching practices. Turkish Journal of Education, 3(4), 4-14.

He, C., \& Yan, C. (2011). Exploring authenticity of microteaching in pre-service teacher education programmes. Teaching Education, 22(3), 291-302. doi: 10.1080/10476210.2011.590588

$\mathrm{Hu}, \mathrm{C}$. (2008). Research into microteaching in application of mathematics teaching theory. Journal of Chongqing Normal University, 1, 87-90.

Karataş, F. Ö., \& Cengiz, C. (2016). Özel öğretim yöntemleri II dersinde gerçekleştirilen mikro-öğretim uygulamalarının kimya öğretmen adayları tarafindan değerlendirilmesi. Kastamonu Eğitim Dergisi, 24(2), 565-584.

Klinzing, H. G., \& Floden, R. E. (1991). The development of microteaching movement in Europe. Paper presented at the Annual Meeting of the American Educational Research Association, Chicago.

Kpanja, E. (2001). A study of the effects of the video tape recording in microteaching training. British Journal of Educational Technology, 32(4), 483-486. doi: 10.1111/1467-8535.00215

Lu, C., Tsai, C., \& Hong, J. (2008). Use root cause analysis teaching strategy to train pre-service science teachers. US-China Education Review, 5(12), 47-53. Retrieved from ERIC database. (ED503886).

Mergler, A. G., \& Tangen, D. (2010). Using microteaching to enhance teacher efficacy in pre-service teachers. Teaching Education, 21(2), 199-210. doi: 10.1080/10476210902998466

Molina, R., Fernandez, M. L., \& Nisbet, L. (2011). Analyzing elementary preservice teachers' development of content and pedagogical content knowledge in mathematics through microteaching lesson study. In M. S. Plakhotnik, S. M. Nielsen \& D. M. Pane (Eds.), Proceedings of the Tenth Annual College of Education and GSN Research Conference (pp. 162-168). Miami: Florida International University.

Pauline, R. F. (1993). Microteaching: an integral part of a science methods class. Journal of Science Teacher Education, 4, 9-17.

Ravitch, D. (2007). Challenges of teacher education. Journal of Teacher Education, 58(4), 269-273. Retrieved from ERIC database. (EJ771933).

Sevim, S. (2013). Mikro-öğretim uygulamasinin öğretmen adaylari gözüyle değerlendirilmesi. Dicle Üniversitesi Ziya Gökalp Eğitim Fakültesi Dergisi, 21, 303-313. 
Singh, Y. K., \& Sharma, A. (2004). Micro teaching. New Delhi: APH Publishing.

Subramaniam, K. (2006). Creating a microteaching evaluation form: the needed evaluation criteria. Education, 126(4), 666-677. Retrieved from ERIC database. (EJ765785).

Uzun, N., Keleş, Ö., \& Sağlam, N. (2013). The effect of microteaching applications in environmental education. Çukurova University Faculty of Education Journal, 42(1), 13-22. 